\title{
29. EARLY NEOGENE BASE-OF-SLOPE SEDIMENT AT SITE 397, DSDP LEG 47A: SEQUENTIAL EVOLUTION OF GRAVITATIVE MASS TRANSPORT PROCESSES AND REDEPOSITION ALONG THE NORTHWEST AFRICAN PASSIVE MARGIN
}

\author{
Michael A. Arthur, ${ }^{1}$ Department of Geological and Geophysical Sciences, Princeton University, \\ Princeton, New Jersey \\ and \\ Ulrich von Rad, Bundesanstalt für Geowissenschaften und Rohstoffe, D3000 Hannover 51, \\ Postfach 510153, Federal Republic of Germany
}

\begin{abstract}
At Site 397 , nearly continuous coring and a total penetration of 1453 meters revealed a thick but geologically complex and intriguing Neogene sediment wedge (1300 m thick) directly overlying Lower Cretaceous (Hauterivian) strata on the upper continental rise off Cape Bojador. A major erosional event stripped sediment from the upper continental rise and lower slope, probably during Oligocene time and produced a hiatus of approximately $100 \mathrm{~m} . \mathrm{y}$. This event may have been related to enhanced geostrophic currents scouring the base of the continental slope, and to critical overloading of sediment on the slope during a concurrent regression. Slumping of slope sediment and cutting of submarine canyons continued from early through middle Miocene. A thick sequence $(554 \mathrm{~m})$ of slump units, debris flow units, intercalated mud turbidites, and turbiditic sands accumulated during this time on the upper continental rise. Slope gradients gradually decreased, and during early-late to middle Miocene about 200 meters of slumped hemipelagic marls and turbiditic sands intercalated with undisturbed hemipelagic marls were deposited. By early-late Miocene time, redeposition of sediment had ceased at the site. Most sediment deposited in the region of Site 397 during early through middle Miocene time was derived from nearby slope environments with some contribution of calcareous biogenic detritus and coarse quartz, glauconite, and phosphate from outer shelf settings. Volcaniclastic debris flow units or turbidites arrived at the site during middle Miocene time (17.5 to 15.5 m.y.B.P.), probably originating from near Fuerteventura. These may record an early shield-building phase on the eastern Canary Islands.
\end{abstract}

\section{INTRODUCTION}

Site 397 (Holes 397/397A) is located on the uppermost continental rise off northwest Africa in a water depth of 2900 meters (Figure 1). Penetration of 1453 meters with nearly continuous coring revealed a complex Neogene sequence nearly 1300 meters thick overlying Hauterivian dark gray mudstones alternating with thin siderite layers. The drilling of this site has allowed study of an unexpected thick sequence of displaced sediments of early to middle Miocene age (lithologic Unit 4, $544 \mathrm{~m}$ thick, Cores 397-79 through 104 and 397A-2 through 34-1), as shown in Figure 2. These strata consist of chaotic pebbly mudstone; dark colored, graded, massive to laminated silty mudstone; thin, graded quartz and foraminiferal sandstone and siltstone beds; slumped hemipelagic marlstone; and occasional, intercalated, thin, bioturbated mudstone or marlstone units.

\footnotetext{
${ }^{1}$ Present address: Scripps Institution of Oceanography, La Jolla, California.
}

In addition, several thick volcaniclastic conglomerate and sandstone beds occur in the middle Miocene portion of this sequence, e.g., Cores 397-79, 80, 81, 84, 85, and 397A-6 and 7 (see Schmincke and von Rad, this volume). The vertical sequence of lithotypes and sedimentary structures in this complex sequence represents a gradual stabilization of slopes and sedimentation following the erosion, slumping, and incision of the preMiocene upper rise and lower slope sediment along the northwest African margin. Slopes of the erosion surface probably exceeded values of three to seven degrees, and the earliest sediment to be deposited on this surface in latest Oligocene-early Miocene time was rapidly slumped and resedimented at the base of the slope. Chaotic debris flow units and slump deposits at the base of the Neogene section in Site 397 gradually give way to turbidite sedimentation and minor slides and slumps (Unit 3, Cores $397-57$ through 79,544 to 752 sub-bottom) and eventually to hemipelagic drape from the late Miocene, indicating reduced slope gradients and stabilization of sediment on the lower slope and upper rise. 

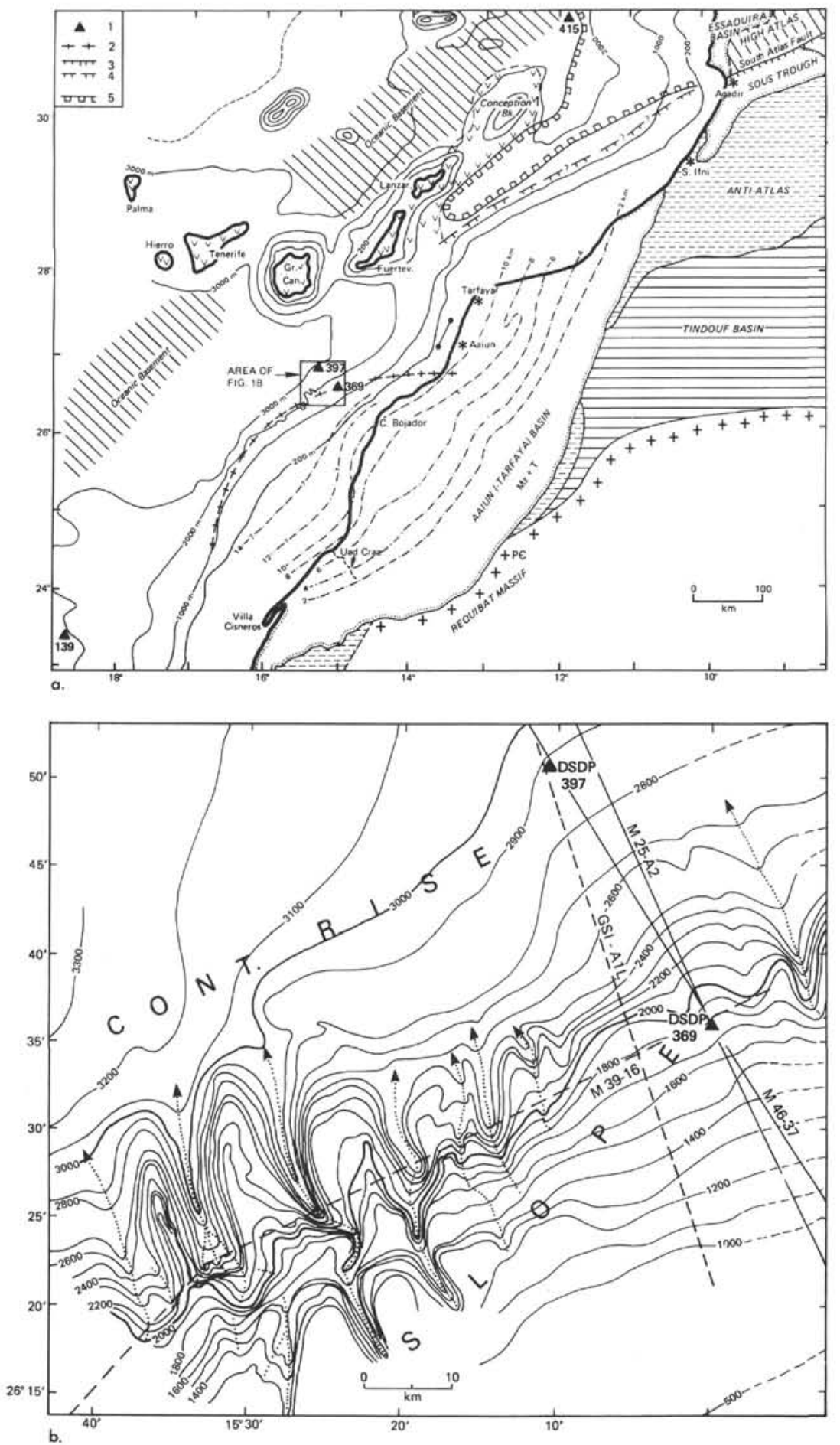

Figure 1. (a) Index map to the location and geologic setting of Site 397 off Cape Bojador between the Aaiun-Tarfaya Basin and the Canary Islands and vicinity. $1=D S D P$ sites; $2=$ Axis of slope anticline (Hinz et al., 1974); 3, 4 = Major fault and fracture zones; $5=$ Limit of offshore "salt basin" (Beck and Lehner, 1974); other features labeled; (b) Location map of Sites 397 and 369 showing bathymetry, axes of major lower slope submarine canyons (dotted arrows), and seismic profiles (modified after von Rad et al., in press). 

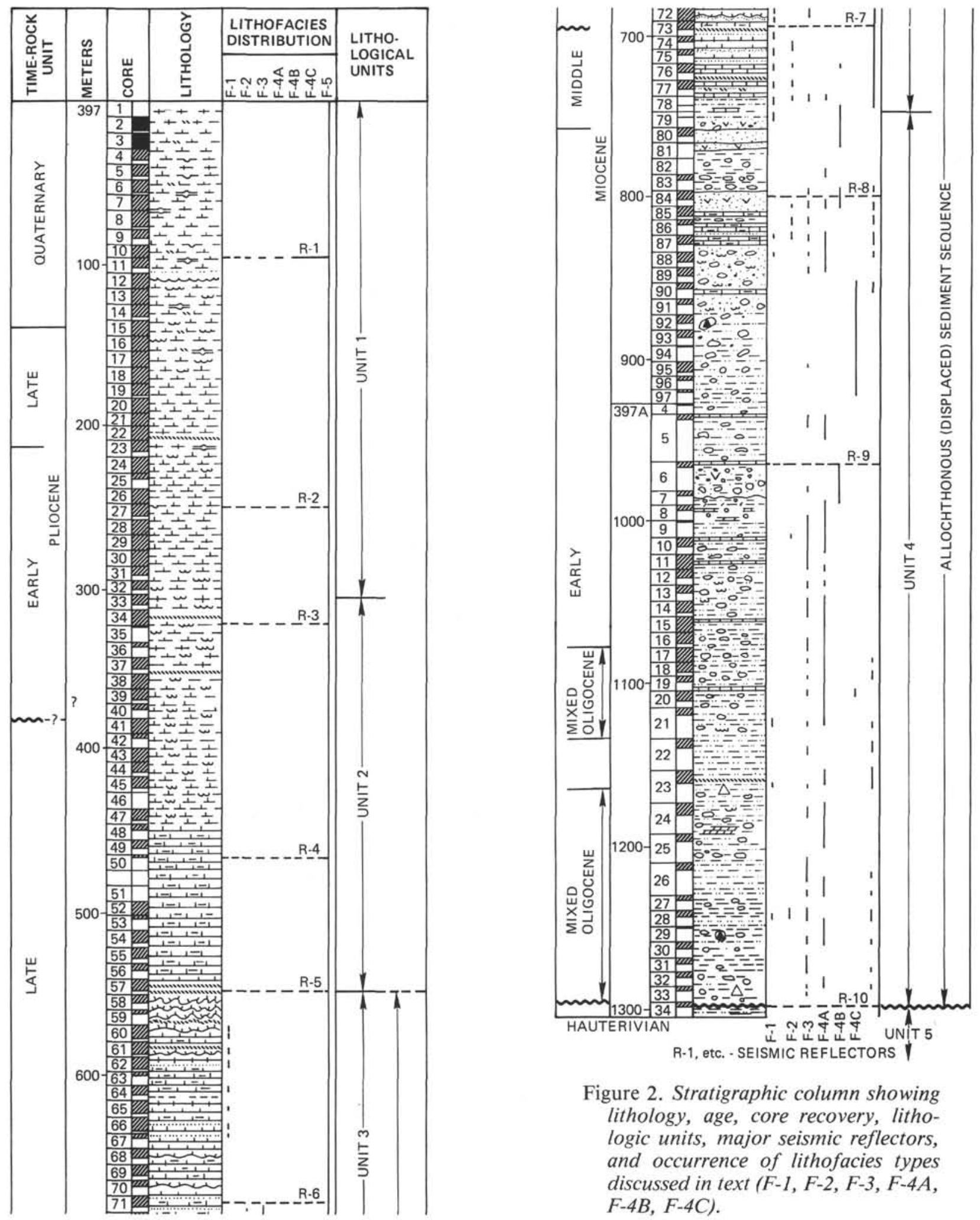

Figure 2. Stratigraphic column showing lithology, age, core recovery, lithologic units, major seismic reflectors, and occurrence of lithofacies types discussed in text $(F-1, F-2, F-3, F-4 A$, $F-4 B, F-4 C)$. 
In this paper, we present descriptions of the various sedimentation units within the pile of lower Neogene displaced sediment, and discuss the nature and composition of sources for the redeposited sediment, processes of redeposition, and implications of the evolution of the vertical sequence.

\section{BACKGROUND AND GEOLOGIC SETTING}

Submarine sliding and slumping is now known to be an important geologic process occurring along continental slopes on passive margins in the Quaternary (e.g., Heezen and Ewing, 1952; Moore, 1961; Heezen and Drake, 1964; Lewis, 1971; Jacobi, 1976; Embley, 1976; Stanley and Silverberg, 1969; Stanley, 1970; Seibold and Hinz, 1974; Moore, 1977). Slides and slumps may generate other gravitative sediment flows including debris flows and turbidites (e.g., Hampton, 1972; Midleton and Hampton, 1973; Embley, 1976). These deposits are found progressively farther away from the site of slumping. Individual debris flows, for example, may travel up to 500 to $700 \mathrm{~km}$ from the point of generation on very low gradient slopes (as low as $0.1^{\circ}$ ), although Stanley and Unrug (1972) have stated that mass flows are most important only at the base of slope or within submarine canyons (see also Shepard and Dill, 1966; Morgenstern, 1967; Stanley, 1974). The causes of these large Quaternary and Recent sediment slides and debris flows are as yet poorly understood, but a number of authors suggest that Quaternary slide events may be related in some way to glacial-interglacial sea level changes (Stanley and Silverberg, 1969), while other authors suggest earthquake activity (e.g., Heezen and Ewing, 1952).

It is difficult presently to evaluate the relative importance of gravity flow depositional processes along continental slopes in earlier geologic epochs. Numerous examples of ancient pebbly mudstone and related sediments which are similar to the above-cited modern redeposited sediment units and are inferred as being submarine base-of-slope deposits have been described and reviewed in the literature (e.g., Stanley and Unrug, 1972; Stanley, 1969, 1975; Walker and Mutti, 1973). These ancient deposits are sometimes difficult to place in a firm regional paleogeographic framework because of structural complications, tectonic overprints, and lack of exposure. The early Neogene sequence at Site 397 provides a unique opportunity to study submarine base-of-slope processes because the results of drilling can be placed in the context of the evolution of the northwest African passive margin off Cape Bojador. This context is established by coordination of drilling data with extensive geophysical surveys of this region (Seibold and Hinz, 1974; Hinz, this volume; Wissmann, this volume), dredging and piston core information from the upper rise and slope (von Rad et al., 1978), and results of previous drilling (see Figure 1) on the upper slope just $32 \mathrm{~km}$ landward of Site 397 (Lancelot, Seibold, et al., 1978; Leg 41, Site 369) and on the outer continental rise (e.g., Berger and von Rad, 1972; Leg 14, Sites 139 and 140).

\section{LITHOLOGY AND COMPOSITION}

The main sediment to be discussed here comprises lithologic Unit 4 (see Site 397 Report) i.e., Sections 397-79-2 to 397A-34-1, representing a total thickness of about 544 meters (Figure 2) and Unit 3 (Cores 397-57 through 79,544 to $752 \mathrm{~m}$ sub-bottom). The age of these slumped hemipelagic marls, conglomerates, pebbly mudstones, sandy pebbly mudstones, mudstones, turbidites, and volcaniclastic conglomerates-sandstones ranges from early Miocene with intermixed reworked middle/late Oligocene to middle Miocene. Resedimentation of this material on the upper continental rise appears to have taken place shortly after initial deposition upslope, because sedimentary clasts within pebbly mudstones have generally the same age as pebbly mudstone matrix and intercalated hemipelagic mudstone, locally, however, older reworked material is present.

\section{Lithofacies Descriptions and Definitions}

A variety of interbedded lithotypes is present, and in order to facilitate description and sampling onboard ship we assigned a numbered designation to each major lithotype within the displaced sediment interval (similar to Walker and Mutti, 1973; Ricci-Lucchi, 1975). Five major lithofacies were recognized based on such parameters as grain size and sorting, color, mineralogy and clast composition, carbonate content, and sedimentary structures. Although each major lithofacies type has a distinct end-member as defined in Core 397-87 (see Plate 1), there are some gradational intervals which could not be easily placed in a pigeon-hole classification. Subdivision is based on lithologic descriptions from smear slides, thin-sections, visual description of the sedimentary fabric, shipboard and shore-based $\mathrm{CaCO}_{3}$ analyses, organic carbon analyses (shipboard, DSDP shore-based data, and data from Cornford et al., this volume), coarse fraction examination, and clast description. Paleontological information provided by M. Cita, G. Lutze, P. Cepek, and F. Wind have aided in description and interpretation.

Lithofacies F-1 through F-4 are interpreted as displaced or allochthonous sediment; each type probably had a somewhat different source and mode of transport and deposition. Not all lithofacies types occur together; several of them typify only certain portions of the sequence. There appears to be a genetic relationship between several types (e.g., F-4A and F-3), as well as an overall evolution from rapid deposition of material transported primarily as slumps and debris flows (F-4) to deposition mostly from turbidity currents or turbid layer transport (F-1, F-2 and F-3) and slumping of hemipelagic layers. The lithofacies representing intervals of "autochthonous" sedimentation (F-5) will be discussed first. 


\section{Lithofacies F-5}

Throughout lithologic Units 4 and 3, the displaced (or allochthonous) sediment types are interbedded with a lithotype interpreted as the product of relatively slow hemipelagic sedimentation (autochthonous), although terrigenous coarse and fine fraction components (Diester Haass, this volume; Chamley and d'Argoud, this volume) and air-blown desert quartz and volcanic debris are ultimately derived from the continents or shallow water environments. These nannofossil marlstones to limestones (F-5) are characterized by light blue-gray to green-gray colors (typically 5B 7/1-5/1). Carbonate contents in F-5 range from 20 to 70 weight per cent, with lowest values near the base of the section increasing toward the upper part of lithologic Unit 4. Sediments of lithofacies F-5 are generally marly nannofossil chalks to nannofossil marlstones. Organic carbon contents are generally low, ranging from 0.20 to 0.60 weight per cent. Bioturbation is common with moderate to intense mottling as the conspicuous texture. Clay-size material predominates, but F-5 sediment may be slightly silty or sandy where a higher foraminiferal content is present. Clay minerals compose most of the terrigenous fraction (predominantly montmorillonite in Unit 4; Chamley and d'Argoud, this volume), but quartz is common and can amount to up to 10 per cent of the total composition. Pyrite is ubiquitous in trace amounts. The relative proportion of Lithofacies F-5 in the sedimentary column increases upward from the base of lithologic Unit 4, becoming most prevalent above Core 397-86 (see Figures 2, 3).

The most conspicuous differences of Lithofacies F-5 from all allochthonous lithofacies (see Plate 3, Figure 1) are: (a) the large proportion of planktonic relative to benthic foraminifers; (b) the general lack of graded bedding or lamination; (c) the intense burrow mottling of the apparently more slowly deposited sediment (see Plate 2, Figures 3 and 4); and (d) the generally light color which becomes lighter higher in the sequence.

A fine, streaky lamination is sometimes present (Plate 2, Figure 2). It might have been produced partly by the horizontal shearing of small burrows and mottles during downslope creep. Such lamination often occurs beneath slumped horizons in lithologic Unit 3 (e.g., Sections 397-70-1 and 66-1; Plate 2, Figure 1). Other laminated intervals suggest reworking by bottom currents and a comparative scarcity of benthic infauna.

Bioturbation or burrow mottling is common in most intervals of Lithofacies F-5 and structures are diverse (Plate 2); traces of burrowing organisms include Teichichnus, Chondrites, and Zoophycos. Reducing conditions prevailed in the sediment soon after deposition, leading to formation of disseminated iron sulfide minerals and concentrations in association with many burrows. Also common are halo burrows which appear to

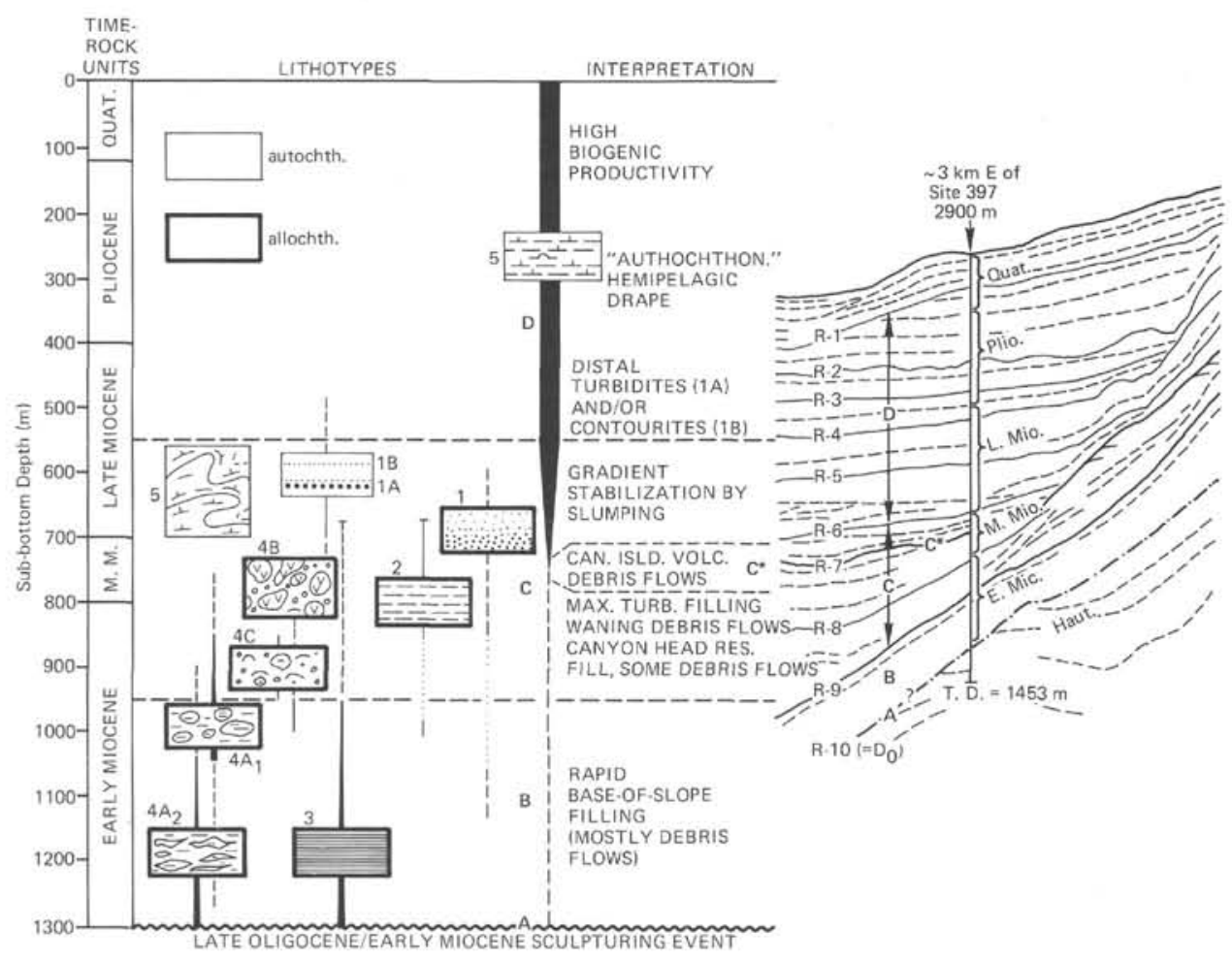

Figure 3. Schematic drawing showing vertical evolution of allochthonous (displaced) sediment on the upper continental rise at Site 397. A, B, C, and D mark major phases discussed in text. These phases are shown on drawing of portion of seismic profile M25-A2 (to right). 
represent a diagenetic front formed around burrows (Plate 2, Figure 2) due to reduction of iron in association with organic matter concentrated in burrow fillings and outward migration of reduced iron species into the sediment. Burrow traces are typically horizontal but vertical traces do occur (Plate 2, Figure 4). Multiple feeding traces are also common with Chondrites or other fucoid-like feeding systems often confined only to burrows of larger organisms. The intensity and diversity of bioturbation in these sediments are impressive. Lithofacies F-5, where examined, contains remains of benthic foraminifers of only lower-middle bathyal depth habitats (Lutze, Site 397 Report), which are interpreted as the indigenous fauna on the uppermost continental rise where Site 397 is located. This is further evidence for the primarily authochthonous origin of F-5.

The allochthonous facies types (F-1 through F-4) are burrowed only at their upper contact with overlying Lithofacies F-5, usually to a depth of less than 5 to $8 \mathrm{~cm}$. Such burrows are commonly filled with material from the overlying hemipelagic calcareous sediment. Layers of sediment and clasts of F-5 type are included with some thick slump or debris flow sequences (Lithofacies F-4). Although interpretation is often difficult, many of these burrowed layers probably represent material caught up in slumps or debris flow units rather than pauses in gravitative sedimentation.

\section{Lithofacies F-1}

Over 80 sand or silt layers (about one-third of which are graded) were recorded in Site 397 below Core 59 in lithostratigraphic Units 3 and 4. Some dark colored, thin, sand or silt layers are the basal portions of lithofacies F-2 or F-3 (defined in next section), but most of the sand or silt layers of white to light gray color are defined as lithofacies F-1. These are most common from Cores 397-59 to 89. They are well-sorted quartzose, foraminiferal fine-grained sandstones (occasionally sandy siltstones) of 0.5 to $80 \mathrm{~cm}$ thickness. Most sand layers are between 2 and $10 \mathrm{~cm}$ thick, except in Cores 397-71 through 78 where individual beds are substantially thicker (10-60 cm, e.g., Plate 5, Figure 1). Graded bedding is common, but most layers are massive to finely laminated; basal contacts are sharp, while upper contacts are sharp to gradational and bioturbated (Plates 5 and 6). Quartz and planktonic foraminifers are the dominant constituents, usually occurring in roughly subequal amounts. These sand layers may contain up to 50 per cent quartz, 20 to 50 per cent planktonic foraminifers, and lower amounts of calcareous nannofossils, heavy minerals (including pyrite), glauconite, feldspar, benthic foraminifers, mica, clay, and occasionally volcanic detritus (e.g., glass). Carbonate contents range from 10 to 60 per cent, and many $(\mathrm{F}-1)$ sandstone beds are calcite cemented below Section 397-79-3. For this reason, no detailed grain size analyses were made. Organic carbon contents are typically very low $(<0.2 \mathrm{wt}$. $\%$ ), but concentrations of organic material may occur at the base of some beds.
Lithofacies (F-1) sediment appears to have been derived from reworking of shelf materials as well as deeper water biogenic components. Subangular to rounded quartz grains are abundant, and glauconite, as well as some phosphatic material, is a common but more minor constituent and may have been partly reworked from older Tertiary sediments exposed on the northwest African shelf (e.g., Summerhayes et al., 1976). Some poorly sorted sands (Sections 397-72-3, 4) contain more shallow-water calcareous biogenic detritus (bryozoans, pelecypod fragments, shallow-water benthic foraminifers) suggesting derivation directly from outer shelf or uppermost slope sources. Most of the sand/silt beds probably represent the distal ends of turbidity currents or spillover from fan channels near the site, based on the general lack of graded bedding (common Bouma intervals $T_{d e}$ ). Some of the turbidity currents may have flowed downslope from the apex of the longitudinally shaped south Canary Island Channel southwest of the Atlas Mountains. Certain "winnowed" foraminiferal sand layers with ungraded, massive texture or faint lamination may be the product of reworking and sorting by bottom currents (e.g., Sample 397A-2-2, 24-29 cm; Plate 6; Figure 2). See Plates 5 and 6 for examples of Lithofacies F-1.

\section{Lithofacies F-2 and F-3}

These lithofacies are discussed together because they are very similar in lithology and composition and probably intergradational. The main distinction between the two is in color and organic carbon content. Lithofacies F-2 is defined as light colored (olive-tan to olive-green and green-gray) marlstone and silty marlstone, often with a thin silt or sand layer ( $<2 \mathrm{~cm}$ thick) at the base grading upwards to laminated or massive claystone to marlstone. Individual beds are typically burrowed in the upper 5 to $10 \mathrm{~cm}$ when overlain by F-5 (most common relationship). The thickness of F-2 layers ranges from 3 to $30 \mathrm{~cm}$. Lithofacies F-3 consists of dark greenish gray (5Y: $4 / 4$ to $5 \mathrm{G} 4 / 1$ ) and olive-gray claystone and silty claystone. Some thin silt layers $(<2 \mathrm{~cm})$ occur also at the base of beds of F-3; some F-3 units exhibit graded bedding but most are massive to laminated and range from $10 \mathrm{~cm}$ to several meters in thickness (atypically thicker than most Lithofacies F-2). Grading occurs usually only in the lower 5 to $50 \mathrm{~cm}$ of individual units. Lithofacies F-3 typically has higher organic carbon content than F-2 ( 0.6 to 4.6 wt. $\%$ versus 0.8 to 3.7 wt. $\%$; see Figures 6 and 7) and somewhat lower carbonate content (ranges from 5 to $35 \mathrm{wt}$. $\%$, possibly to $50 \%$ based on smear slides versus 25 to $50 \mathrm{wt}$. $\%$ and possibly higher based on smear slide determinations).

Lithofacies F-3 occurs most prominently in Cores 397A-8 through 34 but is found up to Core 397-59. Lithofacies F-2 is most common in Cores 397-72 through 87 (and 397A-1, 2) and only occasionally in deeper levels (e.g., 397A-10 and 28); the F-3 type is far more abundant throughout the sequence.

Quartz and planktonic and benthic foraminifers are the most common sand-sized and silt-sized constituents 
in F-2 (typically 3 to $25 \%$ sand and 10 to $30 \%$ silt). The silt-sand fraction of F-3 contains quartz, planktonic foraminifers, glauconite, reworked aragonitic Buliminacea, phosphatic particles, and some shallow water calcareous biogenic elements (Plate 7, Figure 4). Sediment in Lithofacies F-3 was probably derived from an original upper-slope environment under the influence of the oxygen-minimum layer. This would explain the high organic carbon contents, abundance of reworked Buliminacea (typical fauna of low-oxygen upper-slope environments; see Zobel in von Rad et al., 1978), and content of other shallow-water faunal remains (Lutze in Site 397 Report). Lithofacies F-2 is most similar in composition to hemipelagic sediment found in somewhat better oxygenated slope environments (e.g., as in Site 369; Lancelot, Seibold, et al., 1978). Both lithofacies probably represent mud turbidite layers (see Hesse, $1975 \mathrm{a}$, for terminology and criteria for recognition) deposited both from turbid layer transport (dilute suspensions and shelf spillover) and more low density turbidity currents (more distal ends of upper slope slump events?).

Differentiation of each facies is sometimes difficult. For example, all gradations of color occur between the lightest F-2 and darkest F-3 layers. Also, if either type contains pebbles or clasts, they are classified as a member of Lithofacies F-4. In fact, F-3 layers often follow deposition of F-4A units. Higher sand or silt content in some of the thinner F-2 or F-3 units causes an apparent gradation with Lithofacies F-1. See Plates 1 and 7 for examples of Lithofacies F-2 and F-3.

\section{Lithofacies F-4}

These pebbly mudstones, conglomerates, and conglomeratic sandstones (poorly sorted chaotic units or disorganized conglomerates of Walker and Mutti, 1973) occur throughout the allochthonous sediment sequence (Cores 397-59 to 397A-34) but vary in clast composition, texture, and internal fabric upward. Three basic members of Lithofacies F-4 have been differentiated:

Lithofacies F-4A consists of mudstones with matrix similar to F-3. Clasts are typically from 0.1 to $5 \mathrm{~cm}$ (maximum $15 \mathrm{~cm}$ ) in diameter and consist predominantly of dark gray to light green gray claystone and marlstone of the same general age as the dark gray to grayblack matrix of each pebbly mudstone (Table 1). Sedimentary clasts seem to have been soft or semi-indurated during transport. However, lithified clasts of dark gray to black marlstone and claystone and lighter colored limestone are found occasionally and range from Early to Late Cretaceous (Table 1). Most of the clasts in pebbly mudstone units were derived from sediment originally deposited on the slope and similar in composition to F-5, F-2, and F-3 (as described above). Lithofacies F-4A has two basic subtypes: $\mathrm{F}-4 \mathrm{~A}_{1}$ is a pebbly mudstone containing undeformed clasts (Plate 1); F- $4 \mathrm{~A}_{2}$ consists of stretched, pulled-apart, and folded clasts (Plate 8, Figures 2-4). Lithofacies $\mathrm{F}-4 \mathrm{~A}_{2}$ predominates and occurs in the interval from Cores $397-72$ to 397 A-34 and mainly from $397-85$ to the base of lithostratigraphic Unit 4; F-4A, comprises roughly 90 per cent of the sediment from 850 to 1000 meters subbottom and 60 to 70 per cent between 1000 and 1300 meters. Individual pebbly mudstone units may be 10 meters thick, but because of incomplete recovery and the narrow core width, it is difficult to discern all individual layers. F-4A units, averaging between 1 to 3 meters thick, are interpreted as debris flow deposits containing sedimentary and biogenic materials representing outer shelf to lower slope environments. Many F-4A units are probably disrupted slumped intervals in that they exhibit crude stratification and pervasive folding. All gradations between slumps and debris flows can be noted. It is often difficult to distinguish between bedding or lamination and stretched and smeared soft clasts because of the narrow view supplied by split cores. Many $\mathrm{F}-4 \mathrm{~A}_{2}$ units having plastically deformed mud clasts exhibit pronounced imbrication (e.g., dips of 0 to $10^{\circ}$ in Section $397-87-2 ; 30$ to $40^{\circ}$ in Cores $397 \mathrm{~A}-12$ and 13 ; and $20^{\circ}$ in Core 397A-23). Clasts apparently either were sheared during downslope movement in a debris flow before they froze at the site of deposit, or continued to plastically flow slowly downslope after deposition (see Plate 8 ). F-4 $\mathrm{A}_{2}$ units are typically succeeded by Lithofacies F-3.

Lithofacies F-4A, occurs mainly in the upper part of lithostratigraphic Unit 4 (Cores 397-72 to 397A-10; about 685 to $1020 \mathrm{~m}$ ). Apparently slopes were less steep during this time and slumps came to rest farther

TABLE 1

Ages of Clasts in Debris Flow Units or Conglomerates ${ }^{a}$

\begin{tabular}{|c|c|c|}
\hline $\begin{array}{c}\text { Sample } \\
\text { (Interval in } \mathrm{cm} \text { ) }\end{array}$ & Description & Age \\
\hline 57 (in toto) & Dark gray & $\begin{array}{l}\text { Late Early Cretaceous } \\
\text { (i.e., similar to late } \\
\text { Hauterivian, good nan- } \\
\text { nofossil preservation) }\end{array}$ \\
\hline $57-2,83-109$ & Light green-gray & $\begin{array}{l}\text { Same age as matrix } \\
\text { (late Miocene) }\end{array}$ \\
\hline $57-4,88$ & Light gray & Albian \\
\hline $57-4,94$ & Light gray & $\begin{array}{l}\text { Same age as matrix } \\
\text { (late Miocene) }\end{array}$ \\
\hline $57-5,7$ & Light gray & Late Aptian \\
\hline $57-5,9-10$ & Light gray & Late Aptian-early Albian \\
\hline $72-3$ & $\begin{array}{l}\text { Dark gray flaggy shale in } \\
\text { sand }\end{array}$ & Miocene \\
\hline $87-3,30$ & Tan to green marlstone & Miocene \\
\hline $87-3,47$ & White marlstone & Turonian \\
\hline $87-3,129$ & Dark green mudstone & Miocene \\
\hline $87-3,131$ & Dark gray mudstone & Miocene \\
\hline $87-3,137$ & White marlstone pebble & Turonian \\
\hline 87 & Dark gray to black clasts & Always Miocene \\
\hline $89-1,24-25$ & Green marlstone & Miocene \\
\hline $89-1,72-75$ & Dark gray mudstone & Miocene \\
\hline $89-1,72-75$ & Dark gray mudstone & Miocene \\
\hline $89-1,80-90$ & Dark gray mudstone & Miocene \\
\hline $89-1,93-100$ & Green-gray marlstone & Miocene \\
\hline $89-1,138-139$ & Light green marlstone & Miocene \\
\hline $89-2,12$ & $\begin{array}{l}\text { Dark gray-green flaggy } \\
\text { mudstone }\end{array}$ & Turonian-early Cenomanian \\
\hline $89-3,65-69$ & Brown mudstone & Miocene \\
\hline 89 & $\begin{array}{l}\text { Light gray to white lime- } \\
\text { stone }\end{array}$ & Post-middle Albian \\
\hline 89 & Dark gray to black clasts & Always Miocene \\
\hline
\end{tabular}

\footnotetext{
${ }^{\mathrm{a}} \mathrm{Age}$ determinations based on calcareous nannofossils (from Frank Wind, personal communication).
} 
upslope; while the resultant debris flows were deposited on the upper rise at Site 397 (see Plates 1, 8, and 10). In Section 397-80-3 (Plate 8, Figure 1) a medium to coarsegrained ungraded muddy sandstone contains small $(<1$ $\mathrm{cm}$ diameter) dark gray to black mudstone clasts and resembles a grain-flow deposit or fully turbulent proximal turbidite (see terminology reviewed by Carter, 1975), as opposed to typical debris flows.

Lithofacies F-4B consists of a series of five sandy, silty, conglomeratic volcaniclastic debris flow units which are interbedded in upper early to middle Miocene deposits about 17.5 to 15.5 m.y.B.P. (Cores 397-78, 79, $80,84,85 ; 397 \mathrm{~A}-6,7)$. These rocks which contain epiclastic or hyaloclastic fragments, as well as nonvolcanic rock fragments, minerals, and fossils are described in Table 2 and in more detail in Schmincke and von $\mathrm{Rad}$ (this volume, see also Plate 9, Figure 1).

Lithofacies F-4C is similar to F-4A, but usually contains fewer sedimentary clasts and more shallow-water calcareous biogenic debris. These units consist generally of poorly sorted quartz-granule-rich fossil set in a dark gray to black clayey matrix. Shallow-water calcareous constituents include fragmented and whole solitary corals, mollusks, echinoids, and benthic foraminifers; also common are light blue to white quartz or quartzite granules, phosphatic oolites, and fish debris. Lithofacies F-4C occurs mainly in Cores $397-88$ to 102 with isolated occurrences below that level (e.g., 397A-20). Units are typically 30 to $80 \mathrm{~cm}$ thick, but may range upwards to 2.5 meters (for composition and texture see Plate 9, Figure 2 and Plate 10, Figure 1). These deposits probably represent periodic flushing of canyon head reservoirs near the shelf edge or on the upper slope (see Lutze and Hinsch, in Site 397 Report).

\section{SEQUENCE EVOLUTION AND SEDIMENT SOURCES}

The suggested sequence of events and interpretation of the evolution of sedimentation processes in the early Neogene is shown in Figures 2 and 3 for Site 397. This evolution can be roughly divided into four stages (Figure 3 ) beginning with the pre-early Miocene sculpturing event (A) which is more thoroughly discussed in Arthur et al. (this volume). The sculpturing event or slope backcutting phase is followed in early to middle Miocene time by a rapid, base-of-slope filling stage (B) during which deposition of debris flows, slump units, and thick mud turbidites contributed most to the accumulation of sediment on relatively steep slopes. Mud and silt/sand turbidites along with some debris flow units (poorly sorted pebbly mudstone, sandy mudstone) and volcaniclastic sandstones and conglomerates $\left(\mathrm{C}^{*}\right)$ were the major sediment types deposited during the episode (C) which represents gradual stabilization of slope gradients

TABLE 2

F-4B Volcaniclastic Sandstones and Conglomerates

\begin{tabular}{|c|c|c|c|c|c|c|c|}
\hline No. of Debris Flow & Cores & Thickness & $\begin{array}{c}\text { Age } \\
\text { (m.y.) }\end{array}$ & Fabric & Major Composition & $\begin{array}{l}\text { Mode of } \\
\text { Deposition }\end{array}$ & Source Area \\
\hline$V-1 A$ & $397-78-4$ & $0.4 \mathrm{~m}$ & 15.5 & & $\begin{array}{l}\text { Pebbly mudstone with about } 5 \% \\
\text { volcanic rock fragments }\end{array}$ & \multirow[t]{3}{*}{$\begin{array}{l}\text { Debris flow or } \\
\text { turbidity cur- } \\
\text { rent }\end{array}$} & \multirow{3}{*}{$\begin{array}{l}\text { Subaerial part of shield of } \\
\text { Fuerteventura(?) (sub- } \\
\text { aerially derived epiclastic } \\
\text { volcanic rock fragments) }\end{array}$} \\
\hline $\begin{array}{l}\text { See V-1 } \\
\text { Schmincke and von } \\
\text { Rad, this volume } \\
\text { (Plates 1-4) }\end{array}$ & $\begin{array}{l}397-79-2 \\
\text { to } \\
80-1\end{array}$ & $\sim 4.5 \mathrm{~m}$ & $16-17$ & \multirow[t]{2}{*}{$\begin{array}{l}\text { Very poorly sorted, very } \\
\text { coarse ss } / \text { cgl. massive, } \\
\text { poorly graded (maximum } \\
\text { site in middle of flow); } \\
\text { maximum clasts }>5 \mathrm{~cm}\end{array}$} & \multirow{2}{*}{$\begin{array}{l}\text { Main components are rounded } \\
\text { to angular generally non-vesicular } \\
\text { tachylite to fully crystallized } \\
\text { basalt and trachyandesitic rock } \\
\text { fragments with admixtures of } \\
\text { trachyte, microgabbro, and } \\
\text { pumice; minerals are replaced } \\
\text { olivine, Ti-augite, and plagioclase; } \\
\text { shallow-water fossils present (see } \\
\text { Plate 5, Schmincke and von Rad, } \\
\text { this volume); matrix is ₹ recry- } \\
\text { stallized smectite (+ carbonates) }\end{array}$} & & \\
\hline$v-2$ & $397-81-1$ & $?$ & $\sim 17$ & & & & \\
\hline $\begin{array}{l}\text { See V-3 } \\
\text { Schmincke and von } \\
\text { Rad, this volume } \\
\text { (Plates } 3,4 \text { ) }\end{array}$ & $\begin{array}{l}397-84-2 \\
\text { to } \\
85-3\end{array}$ & $7.8 \mathrm{~m}$ & $\begin{array}{l}17 . \\
17.5\end{array}$ & $\begin{array}{l}\text { Moderately sorted, medium } \\
\text { sandstone, indistinctly } \\
\text { graded }\end{array}$ & $\begin{array}{l}\text { Dense to moderately vesicular } \\
\text { palagonitized sideromelane } \\
\text { shards, minor igneous rock frag- } \\
\text { ments, and non-volcanic rock } \\
\text { fragments, quartz, and biogenic } \\
\text { debris } \\
\begin{array}{l}\text { Nummulitids (benthic forams) } \\
\text { and bryozoans prove admixture } \\
\text { of shallow-water sediment }\end{array}\end{array}$ & \multirow[t]{2}{*}{$\begin{array}{l}\text { Debris/grain } \\
\text { flow(?) or } \\
\text { turbidity cur- } \\
\text { rent }\end{array}$} & \multirow[t]{2}{*}{$\begin{array}{l}\text { Submarine part of shield o } \\
\text { Fuerteventura(?) (hyalo- } \\
\text { clastites) }\end{array}$} \\
\hline$V-4$ & $\begin{array}{l}397 \mathrm{~A}-6 \\
\text { and } \\
7\end{array}$ & $? 20-30 \mathrm{~m}$ & $\begin{array}{l}17.5 \cdot \\
18.0\end{array}$ & Poorly sorted & $\begin{array}{l}\text { Mixed clayey volcaniclastic- } \\
\text { quartz sandstone (hyaloclastite) } \\
\text { with } 30 \% \text { quartz, } 25 \% \text { altered } \\
\text { palagonite tuff (calcite, etc. re- } \\
\text { placed), } 5 \% \text { feldspar, } 3 \% \text { plank- } \\
\text { tonic foraminifers, mollusks, etc., } \\
\text { in a brownish Fe-rich clay matrix } \\
(35 \%)\end{array}$ & & \\
\hline
\end{tabular}

Note: These rocks which contain epiclastic (i.e., fragmented by erosion) or hyaloclastic (altered glassy debris granulated and shocked at the contact with water) volcanic fragments, as well as non-volcanic rock fragments, minerals, and fossils, have been described and discussed in detail in Schmincke and von Rad (this volume). A short summary is given here. 
and upbuilding of the upper rise. The last stages of downslope movement and redeposition of sediment are seen in folding slump masses of hemipelagic marlstone in the late middle to early late Miocene (nannofossil Zones NN 9 and NN 10). Intercalated with the hemipelagic slump units are thin distal turbidites and possibly current-winnowed sands and silts (contourites?). Sand or silt layers are extremely rare in the hemipelagic drape sequence (D) above 540 meters sub-bottom. The hemipelagic sequence of late Miocene through Quaternary is characterized by marly chalks and oozes and siliceous chalks and oozes resulting from high biogenic productivity in a coastal upwelling system (see DiesterHaass; Cita et al.; Arthur et al., all,this volume). No major downslope movement or redeposition has occurred in the vicinity of Site 397 since late Miocene.

The evolution of the displaced sediment regime and sources of redeposited sediment is also reflected in the record of displaced faunal elements within the sequence (Lutze, Site 397 Report). Benthic foraminifers from the upper slope and the outer and inner shelf off Cape Bojador occur in debris flow units and mud turbidites (F-2, F-3, F-4) from the base of lithologic Unit 4 at 1296 meters sub-bottom to about 530 meters (Figure 4, modified after Lutze). The largest number of displaced species occurs within the lower portion of Phase $\mathrm{C}$ in pebbly mudstones and poorly sorted molluskan and quartz-rich sandy mudstones at about 950 meters subbottom. Only those benthic foraminifers which are expected to live in upper rise lower slope environments were found above 530 meters sub-bottom. Thus we have three major source areas and directions of sediment transport: (1) transverse transport from the southeast (Cape Bojador slope and shelf), (2) transverse/longitudinal transport from the eastern Canary Islands to the north and northeast, and (3) a longitudinal transport from more distant source areas to the northeast.

\section{Pre-Early Miocene Sculpturing Event}

One or more erosional events combined to cut back the lower slope and upper rise off Cape Bojador during the pre-early Miocene. Material was probably slumped and eroded by bottom currents while submarine canyons were incised. The record of sedimentation at Site 397 during a 100-m.y. period (Hauterivian to earliest Miocene) is missing and presumably removed by slumps and current scour on the upper continental rise. The timing and nature of this sculpturing event are discussed in detail in Arthur et al. (this volume). According to von Rad et al. (1978), the first canyon erosion on the intermediate slope off Cape Bojador started during Paleocene to Eocene time. During late Oligocene to earliest Miocene time an accentuated sea level fall moved the strand line beyond the shelf edge and favored slumping and turbidity currents cutting canyons into the lower slope and sculpturing the base of the slope. The important point for consideration here is that, following the main erosional interval (probably in the Oligocene), the first stable sedimentation on the uppermost rise at Site 397 occurred in the earliest Miocene. Any sediment which accumulated prior to this was either swept away by submarine currents or slumped further downslope into the "South Canary Island Channel" (see Figure 1). Initial slopes of the erosional surface probably ranged from $3^{\circ}$ to $7^{\circ}$. In the Meteor $46-37$ profile (Wissmann, this volume) minimal slopes of $1.6^{\circ}$ (upper slope) and maximum inclinations of $15^{\circ}$ (escarpment at the foot of the slope) were measured.

\section{Rapid Base-of-Slope Filling (1300 to about $950 \mathrm{~m}$ sub-bottom)}

The first record of sedimentation following largescale erosion and submarine canyon incision along the upper continental rise and slope off Cape Bojador (Seibold and Hinz, 1974; von Rad et al., 1978; Arthur et al., this volume) consists of massive, thick-bedded, early Miocene (NN 2, N5) dark pebbly mudstones admixed with some mudstones indicating a middle to late Oligocene age (NP 24, P21 - Globorotalia opima opima Zone; e.g., Core 397A-16). These displaced, reworked sediments overlie directly an unconformity spanning most of the Cretaceous and Paleogene and represent the beginning of a rapid, base-of-slope transverse fill from the African margin. Cretaceous and early Tertiary rocks were probably exposed on the continental slope and especially in submarine canyons, where a great variety of allochthonous Cretaceous, Eocene, and Oligocene lithotypes was dredged (e.g., von Rad et al., 1978). However, very little of this material was incorporated into the sediment slumping and flowing to the upper continental rise from earlier Miocene time on. Material derived from the earlier canyon incision and back-cutting of the margin are missing in Site 397 due to the major Hauterivian/early Miocene hiatus and were apparently swept farther seaward. Thus, the major sedimentation at Site 397, beginning in the early Miocene, consists of material which was initially deposited on the slope and which slumped or flowed downward on slopes through canyons and incisions. To our surprise, clasts contained in the sediment are for the most part of the same age or slightly older than the matrix.

The basal contact of the lower Miocene displaced sediment sequence (Unit 4) with the Hauterivian dark gray mudstone with interbedded siderite (Unit 5) occurs in Core 397A-34 and is sharp. Bedding at the top of underlying Unit 5 is horizontal to slightly inclined (maximum $10^{\circ} \mathrm{dips}$ ), whereas dips as great as $30^{\circ}$ characterize the lower part of Unit 4. Due to significantly different drilling rates the contact is disturbed. Therefore, no signs of weathering or subaerial exposure were seen at the contact between the two units. Two 13-cm-thick graded beds of sandstone to silty mudstone occur above the contact and are similar in color and composition (N5 to N6; medium light gray) to the underlying sediment of Unit 5 . This suggests that the earliest sediment to come to rest on the unconformity surface may have been derived from the underlying sediment. Graded and laminated silty mudstone and mudstone rapidly gives way upward to thick pebbly mudstone beds (F-4A) consisting of clayey siltstone matrix surrounding mainly highly stretched pebbles of bluish gray to green-gray marl. The pebbles generally compose 10 to 20 per cent 
of each pebbly mudstone bed and were deformed plastically during transportation and deposition. Pebbles are smeared, pulled apart, and streaked out in a horizontal direction, often giving the appearance of thin lamination. The fabric of these pebbly mudstones suggests either compactional flattening of unlithified clasts, some post-depositional downslope flowage of individual units, or stretching and shear during downslope transport of the flows. Initial local dips of the pre-early Miocene erosional surface may have been high; dips of $20^{\circ}$ to $30^{\circ}$ occur in lamination, bedding contacts, and clast imbrication in the lower part of Unit 4. These dips decrease upward in the sequence. Some post-depositional downslope slippage might have occurred and initial dips could have been over-steeped by this movement. Textures of sediment mass flow units are typically poorly sorted with chaotic arrangement of clasts which are either sheared and stretched $\left(\mathrm{F}-4 \mathrm{~A}_{2}\right)$ or transported relatively undeformed $\left(\mathrm{F}-4 \mathrm{~A}_{1}\right)$; mixtures of the two within individual units rarely occur. This variation in clast deformation suggests a possible relationship to velocity and amount of shear stress and laminar flow within slump or debris flow masses during transport. The clasts in both types of debris flow units seem to have been unindurated and soft during deposition. There is also a general vertical succession of these gravitative mass flow types: pebbly mudstones and chaotic units in the lower part of the sequence are typically of the $\mathrm{F}-4 \mathrm{~A}_{2}$ type where plastic deformation (stretching and folding) of both small and large clasts occurs; up-section, these gradually give way to $\mathrm{F}-4 \mathrm{~A}_{1}$ and $\mathrm{F}-4 \mathrm{C}$ types where clasts are generally undeformed even though apparently initially soft (some already lithified clasts of Paleogene and Cretaceous age were also sedimented in debris flow units of late-early Miocene age). Some of the chaotic units within the lower part of Phase B $(\sim 1100$ to $1300 \mathrm{~m}$ sub-bottom) appear to have undergone gravitational downslope movement in a stage transitional between slumps and subaqueous debris flows (e.g., Core 397A-16; Plate 4, Figure 1). These intervals exhibit very fluid fold structure with both gentle and tight overturned and recumbent folds, often stretched, cut-off, and isolated within the matrix. The bedding and lithologic relations suggest slumping, disruption, and partial fluidization of originally interbedded bioturbated light green-gray hemipelagic mud and dark gray turbiditic mud. Individual mass flow units are up to 10 meters thick, but incomplete core recovery hampers definition of trends in thickness, and amalgamated units are difficult to distinguish from thick single units. These mass flow units are, however, often interbedded with thin beds of undisturbed bioturbated autochthonous marlstones and marly chalks (F-5) as well as thin to moderately thick, dark colored, organic carbon-rich mud turbidites (F-3). Lighter colored mud turbidites (F-2) and thin graded turbiditic sands or silts occur sporadically. Overall, this rapid base-of-slope filling phase resulted in gradually diminished local slope gradients: sediment appears mainly to have been derived from sites of initial deposition on the middle to upper slope. Average sedimentation rates were in excess of 175 $\mathrm{m} / \mathrm{m} . \mathrm{y}$. over a brief interval of about $3 \mathrm{~m} . \mathrm{y}$. (from about 20 to 17 m.y.B.P.).

\section{Gradient Stabilization and Upbuilding of Upper Rise ( $~ 950$ to $540 \mathrm{~m}$ sub-bottom)}

The assignment of the beginning of this phase in sedimentation at Site 397 is rather arbitrary as there is a gradual transition (Figure 3) from rapidly deposited pebbly mudstones (f-4A) and dark turbiditic mudstones (F-3) to more sandy mudstones containing shallowwater calcareous fossil debris (F-4C), lighter colored mud turbidite layers (F-2), and turbiditic sandstones (F-1) intercalated with burrowed marly chalks (hemipelagites; F-5). The seismic profiles across the site (Figure 3) show reflectors which are more steeply dipping between reflectors R-10 and R-9 during Phase B and gradually decrease in inclination between R-9 and R-7 during Phase C. Intervals between seismic reflectors are generally irregular in thickness and somewhat discontinuous. These characteristics are a manifestation of the diversity of sediment sources, local sedimentation events, and slumping and sliding which occurred during Phase C. Dips of bedding and lamination in cores are generally less than $5^{\circ}$ as opposed to apparently steeper dips in sediment from Phase B. Sedimentation rates during Phase $\mathrm{C}$ in the late-early Miocene were very rapid, at from 150 to $175 \mathrm{~m} / \mathrm{m}$.y., but declined substantially during middle Miocene time where two hiatuses were recognized to less than $25 \mathrm{~m} / \mathrm{m}$.y. The sedimentation processes and sources were more heterogeneous during Phase $\mathrm{C}$ than during either Phase B or the succeeding hemipelagic drape, Phase D.

A maximum of reworked shallow-water fossils occurs in sediment at around 900 to 950 meters sub-bottom (at about 18 m.y.B.P., Figure 4). Fragments of shallowwater mollusks, corals, and shelf and upper slope benthic foraminifers are abundant as part of the sand and granule-sized component of sandy and pebbly mudstone units (F-4C) and in some mud turbidite (F-3; F-2) and poorly sorted sand layers. Pebbles in the disorganized pebbly mudstones are similar to those found in lower Miocene debris flow units $\left(\mathrm{F}-4 \mathrm{~A}_{1,2}\right)$. However, they also consist of some lithified clasts of various lithologies ranging from Hauterivian (?) through Eocene (Table 1) similar to pebbly mudstones described from the Cape Bojador slope by von Rad et al. (1978). Those allochthonous sediments were found especially in the latestearly Miocene to middle Miocene. It is evident that much material was redeposited from regions on the middle and upper slope, and possibly from shelf depth. Much of the shallow-water detritus may have been first swept over the shelf edge and deposited in canyon heads or on slopes. It was then brought down to upper rise depositional sites in slumps and debris flows consisting of mixed shelf-slope assemblages and sediment.

A very important volcano-tectonic event is also recorded in sedimentation at Site 397 during Phase C (Cores 397-85, 84, 81, 80, 79; 397A-6, 7). About five thick conglomerate and sandstone units of latest-early 


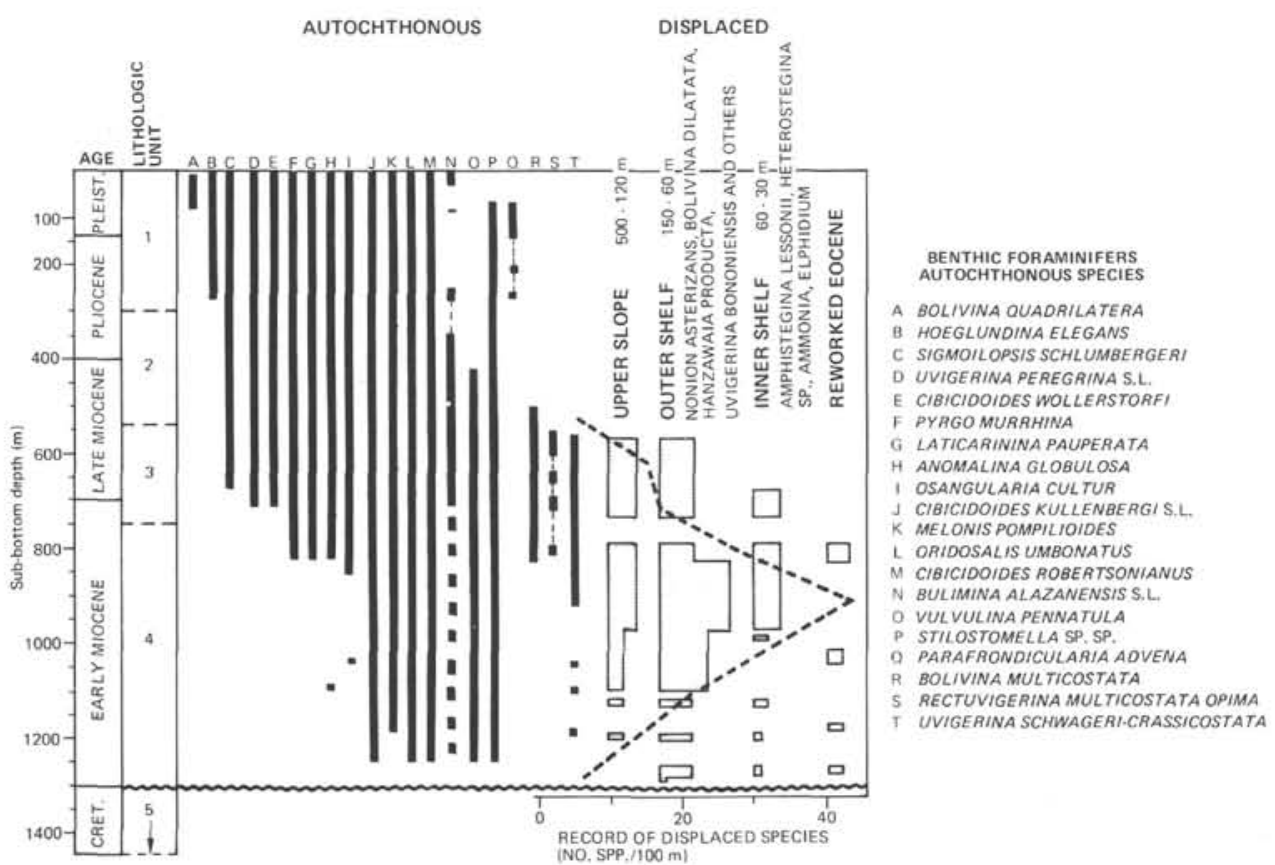

Figure 4. Reworking of benthic foraminifers in displaced sediment from Site 397. Note presence of species from shelf and slope environments, as well as autochthonous species in debris flows and turbidites until mid-late Miocene time. Maximum numbers of reworked species per sample occur in sediment deposited during early Miocene time (modified after Lutze, Site 397 Report).

to middle Miocene 17.5 to 15.5 m.y.B.P.) contain significant amounts of volcanic detritus (Table 2 and Schmincke and von Rad, this volume). Age and mineralogical composition of the rock fragments suggest a derivation from one of the older Eastern Canary Islands, most probably Fuerteventura in the Canary Islands. This sequence of poorly to moderately sorted conglomeratic sandstone and conglomerate probably was deposited from debris flows and turbidity currents flowing down the gradient from Fuerteventura across the "South Canary Island Channel" to Site 397 (Figure 1). Inference on the aerial extent $\left(2000 \mathrm{~km}^{2}\right)$ from seismic profiles (see also Wissmann, this volume) and approximate thickness of units at Site 397 suggest that greater than $40-60 \mathrm{~km}^{3}$ of detritus may have been sloughed off the Fuerteventura shield and deposited as a long narrow tongue during a few instantaneous intervals in the deepest southeastern part of the "South Canary Island Channel" during a 2-m.y. period. The timing of this event suggests a relationship to a comparatively brief, but voluminous submarine shield-building phase of Fuerteventura and an early period of subaerial shield phase (Phase $\mathrm{C}^{*}$ ). Shallow-water fossils (mollusks, bryozoans, oncolites, nummulitids) are found admixed in the conglomerates.

Thick to thin-bedded graded to laminated and massive sands and silty sands (F-1) are common during the upper part of Phase C. The thickest sand layers are recorded in the middle Miocene interval 700 to 750 meters sub-bottom. They consist mainly of detrital quartz, planktonic and benthic foraminifers, glauconite, pyrite, and minor amounts of volcanic glass, feldspar, mica, and phosphatic particles. Several graded, coarse to finegrained sand units of greater than $20 \mathrm{~cm}$ thickness contain a number of different types of calcareous shallowwater fossil debris (Sections 397-72-3 and 4). The sands are most frequent during the interval of slow sedimentation from about Core 397-80 to Core 397-72, but continue from the mid-Miocene hiatus (10.5-12.5 m.y.B.P.) through Core 397-60 (570 m sub-bottom), a period of high accumulation rates $(200 \mathrm{~m} / \mathrm{m}$.y.; Sarnthein, in Arthur et al., this volume) in association with slightly slumped intervals in early-late Miocene time. The turbidites may have been generated by submarine slides, slumps, and debris flows which came to rest farther upslope, or they may be spillover deposits derived from thicker units flowing down canyon or fan channels farther to the north or south (Figure 1); the location of Site 397 apparently occupied an intercanyon position during most of the Neogene. It is not clear from the present available data whether or not major submarine fans were built out during the early Neogene on the rise in the immediate region of Cape Bojador.

Debris flows, including those containing Canary Island volcanic detritus, ceased arriving at the position of Site 397 in the middle Miocene (about 15 m.y.B.P., Core 397-78). Sedimentation rates decreased substantially following this $(<15 \mathrm{~m} / \mathrm{m}$.y. during the middle Miocene, Cores $397-80$ to 72 ) when mainly nannofossil chalk and marly nannofossil chalk with intercalated sand layers as discussed above, were deposited. However, a 1.0 to 2.0 m.y. hiatus (Core $397-72$ at about $690 \mathrm{~m}$ sub-bottom) marks the beginning of an increase in sedimentation rates to greater than $50 \mathrm{~m} / \mathrm{m} . \mathrm{y}$. during 
an interval of periodic slumping and sliding of marly nannofossil ooze and nannofossil ooze. About 31 individual slumped units, which range from about $5 \mathrm{~cm}$ to 2 meters in thickness, were recovered in Cores 397-72 to 57 (690 to $578 \mathrm{~m}$ sub-bottom). Very little stratigraphic mixing occurs within the slumped interval. Detached slump units which came to rest at the site are coeval with the interbedded bioturbated nannofossil chalks having varying clay content. The slumped intervals are internally deformed with tight to gentle folding and some faulting common (Plate 4, Figures 1-3). These units were probably derived from nearby slopes and apparently flowed slowly downslope to the site. A slump deposit in Core 397-57 has incorporated dark colored clasts (Hauterivian [?], late Aptian, and Albian) as well as of the same age as the matrix (early-late Miocene; Wind, personal communication). There appears to be no decrease in thickness of the slump deposits upsection, but slumping suddenly ceases in Core 397-57 at 544 meters sub-bottom, marking the final stabilization of slopes in the vicinity of the site in the early-late Miocene. Sedimentation rates remain high $(75 \mathrm{~m} / \mathrm{m}$.y.) following this period during deposition of nannofossil chalks and marly nannofossil chalks of the hemipelagic drape Phase D (Figure 4). Sea-surface fertility was apparently high from the late Miocene through Quaternary due to enhanced upwelling conditions (see Cita; Diester-Haass and Sarnthein, in Arthur et al; all, this volume). Seismic profiles (Figure 3 ) exhibit numerous parallel reflectors on the upper rise during this time; no evidence of displaced sediment was found.

\section{CAUSES OF MASS WASTING AND VARIATION IN SEDIMENT SOURCES}

The sequence of allochthonous sediment (1300 to 544 m sub-bottom) recovered in Site 397 is a more-or-less typical base-of-slope facies sequence as postulated by Kelling and Stanley (1976) for relatively steep ("young", or "rejuvenated") slopes at prograding passive margins. The debris flow-turbidite-slump-hemipelagite sequence observed in Site 397 is a "fining upward" or "positive megasequence"' (Ricci-Lucchi, 1975), i.e., a successional or on-lapping sequence characterized by the abrupt onset of debris flows on an unconformity (overlying normal marine sediments) and the subsequent decrease of sedimentation rates, vigor of gravitative processes, and slope angle. We have described this sequence and the variation in sediment sources, but we have not offered much insight as of yet to explain why this series of events occurred on this passive margin at this time. Embley (1976) and Jacobi (1976) have described and figured similar sediment slides, slumps, and debris flows of Quaternary age from the passive continental margin of northern Africa deposited on slopes of $4^{\circ}$ to $0.1^{\circ}$. They presented a number of possible explanations for large gravity-induced mass transport events, but could not demonstrate any one definite cause. Among the possibilities to be considered in the case of the Cape Bojador Neogene allochthonous sequence must be: (1) a relation to increased seismic activity during orogenic phases, to fracture tectonics or to volcanic uplift of the margin and the Canary Archipelago; (2) slumping because of excessive rates of sedimentation and overloading of slopes (anomalous pore pressure increase) during deltaic progradation or low sea-level stand; (3) slumping due to oversteepening of slope by the undercutting of geostrophic currents; (4) gas build-up in slope sediment and subsequent pore pressure increase and sediment failure because of high rates of decay of organic matter and variations in the gas/clathrate boundary.

Some combination of the above mechanisms for inducing massive and long-term slope failure and redeposition of sediment is likely. A low stand of sea level occurred during the Oligocene, which may have brought the shoreline out to the shelf edge (Vail et al., 1977); in the late Oligocene, sedimentation rates were above average on the upper slope (Site 369; Lancelot, Seibold, et al., 1978). High sedimentation rates and overloading of the slope may have led to some slumping of sediment at this time. Several slumped units do occur in Oligocene nannofossil marls in the 6-m.y. hiatus between late Oligocene and late Eocene sediment in Site 369 (Core 33). Massive back-cutting of the upper rise and lower slope probably occurred during the Oligocene and possibly earlier. This back-cutting is due, in part, to the action of enhanced geostrophic currents during climatic deterioration, slumping on oversteepened slopes, and cutting of submarine canyons (see Arthur et al., this volume; von Rad et al., 1978).

Increased earthquake activity during the Miocene, possibly earlier, is also likely during Paleogene-Neogene orogenic phases in the Atlas Mountains region (e.g., Dillon and Sougy, 1974) and the uplift of the volcanic Canary Archipelago (Schmincke, 1977). These earthquakes may have acted as tectonic triggers for some of the slides.

High internal gas pressure in the sediment and variation in the gas/clathrate boundary may also have been a factor. Dark colored, relatively organic-carbon-rich, slumped sediment recovered in the early to middle Miocene of Site 397 was probably derived from the upper slope, which was under the influence of an oxygenminimum layer (Figure 5). Large quantities of methane and other gases were present in this organic-carbon-rich (values to 4 wt. \%, see Figures 6 and 7) interval at Site 397 (Whelan, this volume), and sufficient methane may have been produced in similar sediment on the upper slope to raise internal gas pressure to a critical value (see Stoll, 1974), thus favoring or leading to sliding and slumping of slope sediment.

It is difficult to evaluate the relative importance of any one of these possible causes. It appears that the erosion of the upper continental rise lower slope during pre-latest Oligocene time led to further mass-wasting of middle to upper slope and outer shelf sediment during early to middle Miocene time, although no evidence of this event is seen in Site 369, which also occupies an intercanyon position on the upper slope, whereas the Oligocene is missing again on the shelf (Spansah 51A-1 well) and in the Aaiun Basin. Much of the redeposition may have been due to an initially oversteepened and un- 


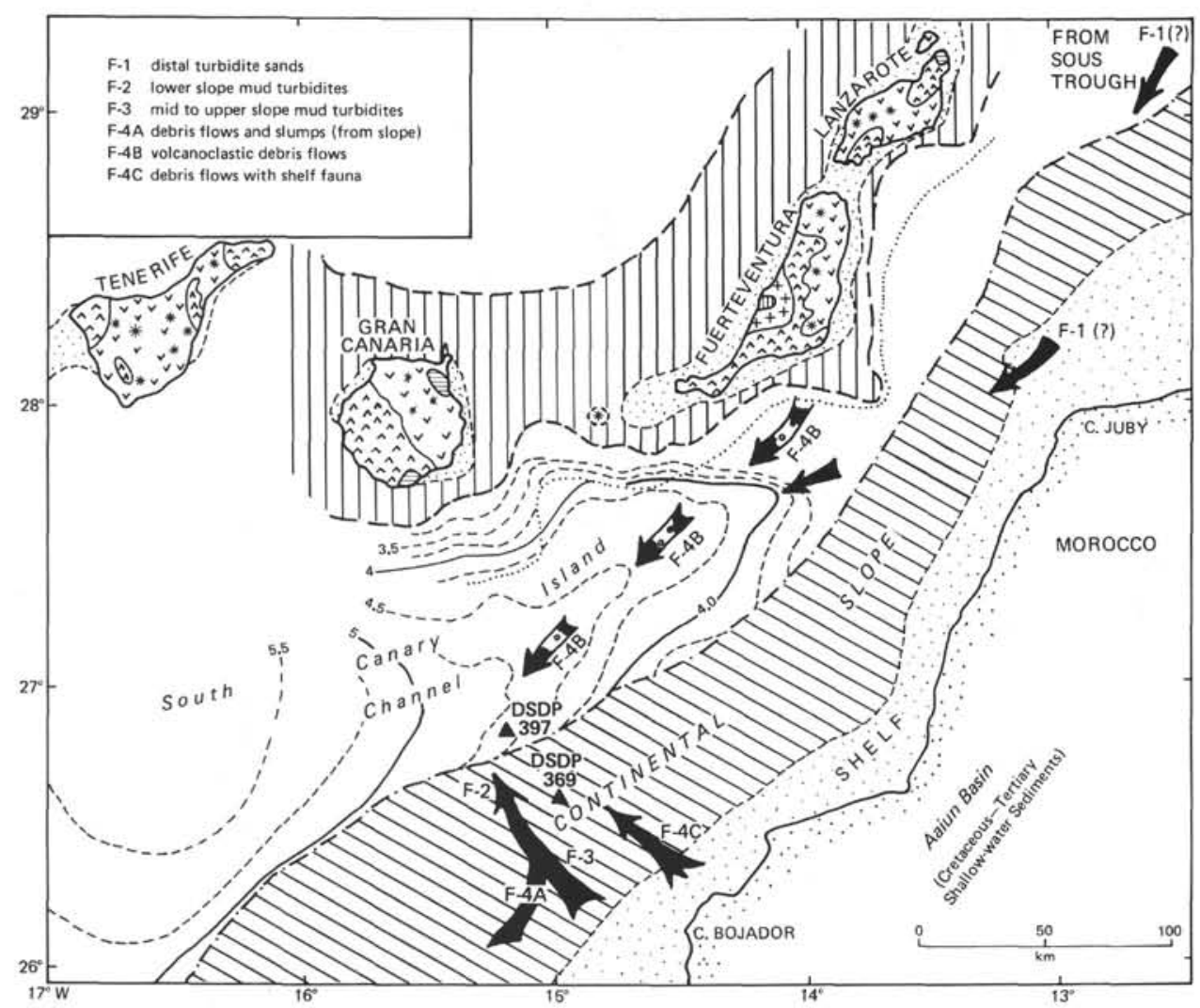

Figure 5. Depth contours of seismic reflector $R-71$ ( $=D_{2}$ of Hinz et al., 1974) in seconds (two-way travel time) between the volcanic mass of Canary Islands and the base of the continental slope (see Wissmann, this volume). Arrows indicate tentative provenance and transport directions of lithofacies types defined in text $(F-1, F-2, F-3, F-4 A, F-4 B, F-4 C) . R-7$ depth contours indicate approximate middle Miocene paleobathymetry (see Schmincke and von Rad, this volume, for explanation of symbols for generalized geology of Canary Islands).

supported slope (see Tucholke and Carpenter, in press, for Quaternary example). The main period of masswasting recorded on the upper rise in Site 397 corresponds to a period of rising sea level (Vail et al., 1977) rather than a low stand. Thus, a high rate of sediment accumulation during a regression was not the most significant factor effecting mass wasting during the early and middle Miocene, but may have been important during the Oligocene, when no sediment accumulated on the lowermost slope and upper rise. If back-cutting of the rise and slope was accomplished by sliding and slumping during the Oligocene, the resulting redeposited sediment must lie farther out in the South Canary Basin or beyond. Submarine canyons and slope valleys which were cut during Paleogene times were filled with sediment beginning in the early to middle Miocene (von Rad et al., 1978).

No further mass-wasting events of the post-middle Miocene are recorded in the sedimentary column of Site 397 or from the sediment on the Cape Bojador slope, even in association with sea-level lowstands during the Quaternary. As previously mentioned, large Quaternary sediment slidesand slumping events are documented farther south along the northwest African margin (e.g., Jacobi, 1976; Embley, 1976) but probably have not been important along the Cape Bojador portion of the margin. This may be due, in part, to the paucity of sediment derived from the adjacent borderland in a stable region of arid climate. It is interesting to note the sharp change

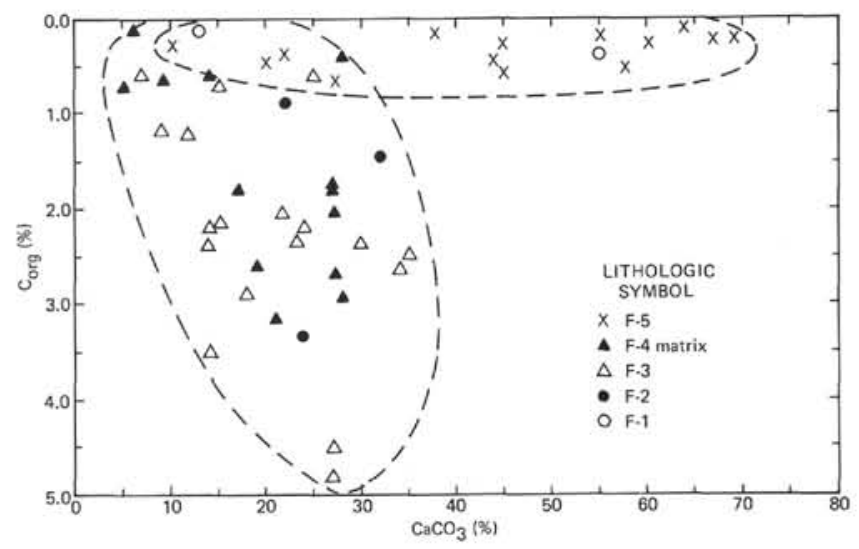

Figure 6. Plot of organic carbon versus carbonate in different lithofacies types within the displaced sediment sequence. Note low $\mathrm{C}_{\text {org. }}$ and higher $\mathrm{CaCO}_{3}$ values of $F-5$ and high $C_{\text {org. }}$ contents of F-3 and F-4 matrix. 


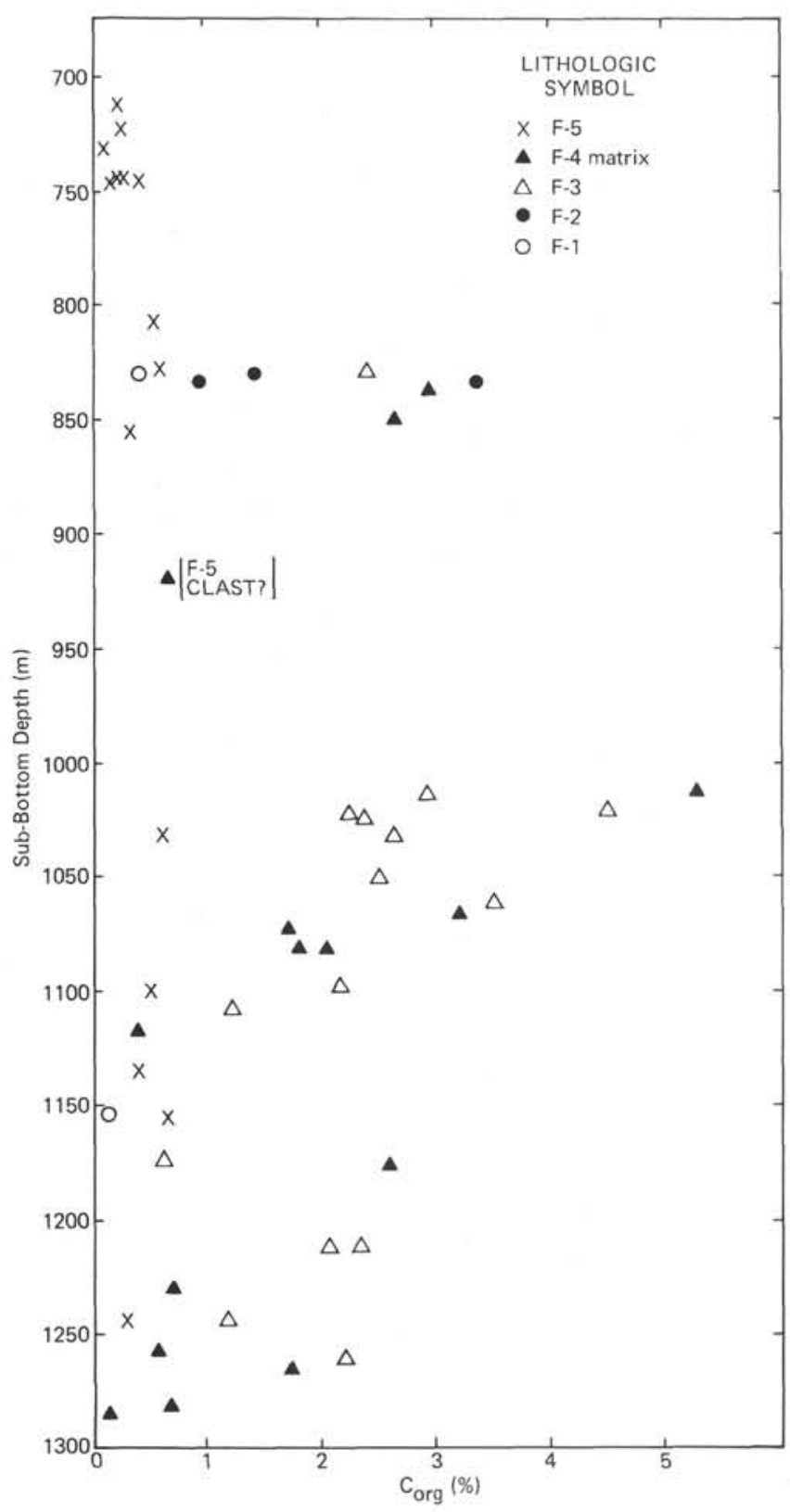

Figure 7. Variation in $C_{\text {org. }}$ content of different lithofacies with depth (and time) within displaced sediment sequence at Site 397. Note: highest $C_{\text {org. }}$ contents near 1000 meters sub-bottom correspond to maximum amount of reworking of upper slope and shelf species of benthic foraminifers (see Figure 4); this maximum probably indicates the derivation of much sediment from upper slope environments under the influence of the oxygen-minimum zone.

in clay mineral composition (Chamley and d'Argoud, this volume) at the boundary between Phases C and D (middle Miocene), from a predominantly monmorillonitic composition to a kaolinite-illite dominated assemblage. Although Chamley and d'Argoud (this volume) have attributed this change to a regional transition from a warm climate with contrasts in seasonal humidity to a more arid climate, the change in the clay mineral assemblage may also have resulted from a change in sediment source. For example, the clay minerals fraction of late Miocene through Quaternary hemipelagic sediment may have been derived from eolian or local stream supply from the adjacent land area (DiesterHaass and Chamley, this volume). The smectite of earlier sediment may have come from drainage issuing from the Anti-Atlas or Atlas Mountains to the north and supplied by southerly along-shore currents to the continental slope at Cape Bojador. The existence of an important sequence of thick fluvial sediment $(1100 \mathrm{~m})$ has been suggested by Wissmann (personal communication) for Miocene time, offshore the present Seguia El Hamra Wadi (northern Aaiun Basin, Figure 1) and to the north (in Daora 1-1 well; AUXINI, 1969). This fluvial input may have contributed to higher accumulation rates of terrigenous material and possible overloading of the steepened slope off Cape Bojador during the early to middle Miocene; probably, it has not been a factor since the late Miocene. However, the Neogene climate in the northwest Sahara was generally humid and subtropical until it deteriorated to an arid, cold climate in late Pleistocene (Sarnthein, in Arthur et al., this volume). Smectites also may have been derived from erosion of older formations on the slope.

\section{CONCLUSIONS}

The sequence of displaced early Neogene sediment cored at Site 397 shows a distinct evolution of sedimentation processes and sources operating at the base of a rejuvenated slope along a part of the passive northwest African continental margin. Based on composition and texture, the above-defined lithofacies show a trend (Figure 3 ) from early Miocene debris flow deposits, slump units, and dark mud turbidites at the base, only occasionally interbedded with thin autochthonous hemipelagic calcareous mudstones through occasional debris flows and sandy mudstones, mud turbidites, and hemipelagic mudstones, interbedded with some sand/silt turbidites and mud turbidites (middle to late Miocene) near the top. Superimposed on this (Figure 3) are several massive volcaniclastic debris flows derived from the Canary Islands in the middle Miocene (see Schmincke and von Rad, this volume). The final sign of decreasing slope instability is manifested in a sequence of contorted beds, probably slumped from nearby during mid-late Miocene times (Cores 397-61 to 57) within otherwise undisturbed hemipelagic muds. Rapidly sedimented hemipelagic marly nannofossil ooze, without signs of significant redeposition $(75 \mathrm{~m} / \mathrm{m} . \mathrm{y}$.), follows deposition of the displaced sediment sequence during the late Miocene to the present.

The sequence in Site 397 demonstrates the progressive decrease in slope gradients (up to $15^{\circ}$ ) during the early to late Miocene, following a major erosional event which resulted in slope retreat, removal of upper rise sediment, and cutting of submarine slope canyons during the Oligocene. Mass-wasting of sediment from the continental slope (including shallow-water shelf 
detritus) continued during the early and middle Miocene and accumulated ( $>540 \mathrm{~m}$ of mainly allochthonous sediments) at Site 397 on the upper rise. The masswasting was in response to oversteepened slope gradients and to critical overloading of slope sediment; possibly, also to increased regional seismicity related to volcanic-tectonic uplift of the Canary Islands archipelago and to tectonic events in the Atlas Mountain region.

Whereas sedimentation in typical, flysch troughs are commonly linked to orogenic activity along active or convergent continental margins. The thick sequence encountered in Site 397 on the upper continental rise of a passive margin does not seem to bear a direct relationship to tectonic activity, although the proximity to the Canary Island Chain and Atlas Mountains to the north may have had some influence on sedimentation. The sedimentary sequence and structure at Site 397, however, has much in common with flysch sequences from presumed fossil and known recent active margin settings (e.g., Quaternary California Borderland, von Rad, 1968, and Moore, 1969; Miocene of Northern Appennines, Ricci-Lucchi, 1975; Cretaceous Pennina Flysch of the Eastern Alps, Hesse, 1956). These similarities lie in bathymetric setting, mixture of sediment transport directions (transverse and longitudinal transport directions), alternation of thin deep-water hemipelagites with thick sequences of shallower water sediments introduced by gravity-driven processes, and continuity of proximal to distal environments seen in the vertical (temporal) and horizontal (spatial) lithofacies sequences whereas long-distance longitudinal transport directions prevail in many fossil flysch basins (Hesse, 1975a) and deep-sea trenches and abyssal plain settings. One significant difference between active and passive margin sequences may be the predominance of sediment derived from adjacent slopes in Site 397 and other base-of-slope passive margin settings. We would like to stress that allochthonous (displaced) sedimentary facies in ancient continental margin settings may not always have tectonic significance and that the tectonic implications of each sequence must be carefully assessed. Information on tectonic setting cannot be inferred from sedimentary sequence and composition alone (e.g., Hsü, 1970). Major unconformities may be overlain by thick non-orogenic displaced sediment sequences in the absence of related major tectonic activity, as in the case of Site 397. On the other hand, our knowledge of the evolution of "passive margins" may be incomplete; there is still a possibility that periodic non-orogenic tectonic adjustments do occur along passive margins (in relation to major regressions and erosional episodes in both shelf and deep-sea settings) causing drastic changes in slope angles and sediment stability. However, we presently favor the combined influences of enhanced deep geostrophic flow and lowered sea levels as the major cause of backcutting of the margin and subsequent gravitative mass-flow events from the Oligocene to late Miocene along the northwest African continental margin off Cape Bojador.

\section{ACKNOWLEDGMENTS}

We thank the other shipboard scientists who contributed thoughtful discussion and data for this study, especially Gerhard Lutze, Floyd McCoy, Michael Sarnthein, George de Vries Klein (Univ. of Illinois), Oscar Weser, and Frank Wind. An earlier version of this manuscript was reviewed by Peter Saddler (U.C. Riverside), who provided many thoughtful comments and suggestions for improvement.

\section{REFERENCES}

AUXINI (Departamento de Investigaciones Petroliferas de AUXINI), 1969. Correlacion estratigraphica de los sondeos perforados en el Sahara Español, Bol. Geol. Minero, Madrid, v. 83 , p. $235-251$.

Beck, R. H. and Lehner, P., 1974. Oceans, new frontier in exploration, Am. Assoc. Petrol. Geol. Bull., v. 58, p. 376-395.

Berger, W. H. and von Rad, U., 1972. Cretaceous and Cenozoic sediments from the Atlantic Ocean. In Hayes, D. E. Pimm, A. C., et al, Initial Reports of the Deep Sea Drilling Project, v. 14: Washington (U.S. Government Printing Office), p. 787-954.

Carter, R. M., 1975. A discussion and classification of subaqueous mass-transport with particular application to grain-flow, slurry-flow, and fluxoturbidites, Earth Sci. Rev., v. 11, p. 145-177.

Dillon, W. P. and Sougy, J. M. A., 1974. Geology of West Africa and Canary and Cape Verde Islands. In Nairn, A. E. M. and Stehli, F. G. (Eds.), The ocean basins and margins: The North Atlantic: New York (Plenum Press), v. 2, p. 315-390.

Embley, R. W., 1976. New evidence for occurrence of debris flow deposits in the deep sea, Geology, v. 4, p. 371-374.

Hampton, M. A., 1972. The role of subaqueous debris flow in generating turbidity currents, J. Sediment. Petrol., v. 42, p. $775-793$.

Heezen, B. C. and Drake, C. L., 1964. Grand Banks slump, Am. Assoc. Petrol. Geol. Bull. v. 48, p. 221-233.

Heezen, B. C. and Ewing, M., 1952. Turbidity currents and submarine slumps and the 1927 Grand Banks earthquake, Am. J. Sci., v. 250 , p. 848-873.

Hesse, R., 975a. Turbiditic and non-turbiditic mudstone of Cretaceous flysch sections of the East Alps and other basins, Sedimentology, v. 22, p. 387-416.

1975b. Turbidite sedimentation systems and the recognition of Cretaceous plate boundaries in the AlpineCarpathian arc, Ninth Internat. Congr. Sedimentology, Nice, v. 4, p. 189-195.

Hinz, K., Seibold, E., and Wissmann, G., 1974. Continental slope anticline and unconformities off West Africa, "Meteor" Forsch.-Ergebn., Reihe C, no. 17, p. 67-73.

Hsü, K. J., 1970. The meaning of the word flysch-a short historical search. In Lajoie, J. (Ed.), Flysch sedimentology in North America: Geol. Assoc. Canada Spec. Paper 7, p. 1-272.

Jacobi, R. D., 1976. Sediment slides on the northwestern continental margin of Africa, Marine Geol., v. 22, p. 1-272.

Kelling, G. and Stanley, D. J., 1976. Sedimentation in canyon, slope, and base-of-slope environments. In Stanley, D. J. and Swift, D. J. P. (Eds.), Marine sediment transport and environmental management: New York (J. Wiley \& Sons, Inc.), p. 379-435.

Lancelot, Y., Seibold, E., et al., 1978. Initial Reports of the Deep Sea Drilling Project, v. 41: Washington (U.S. Government Printing Office). 
Lewis, K. B., 1971. Slumping on a continental slope inclined at $1^{\circ}-4^{\circ}$, Sedimentology, v. 16 , p. 97-110

Middleton, G. V. and Hampton, M. A., 1973. Sediment gravity flows: mechanics of flow and deposition, Soc. Econ. Paleont. Mineral. (Pacific Section) Short Course Lecture Notes. Turbidites and deep-water sedimentation, p. 1-38,

Moore, D. G., 1961. Submarine slumps, J. Sediment. Petrol., v. 31 , p. $343-357$.

1969. Reflection profiling studies of the California continental borderland: Structure and Quaternary turbiditic basins, Geol. Soc. Am. Spec. Paper 107, p. 1-142. 1977. Submarine slides. In Voight, B. (Ed.), Rockslides and avalanches: Natural phenomena: North Holland (Elsevier), v. 1, p. 563-604.

Morgenstern, N. R., 1967. Submarine slumping and the initiation of turbidity currents. In Richards, A. F (Ed.), Marine geotechnique: Urbana, Ill. (Univ. of Illinois Press), p. 189-220.

Ricci-Lucchi, F., 1975. Miocene paleogeography and basin analysis in the Periadriatic Appennines. In Squiyres, C. (Ed.), Geology of Italy: Tripoli (Petroleum Exploration Soc. of Lybia), p. 5-111.

Schmincke, H. U., 1977. The geology of the Canary Islands. In Kunkel, G. (Ed.), Biogeography and ecology in the Canary Islands: The Hague (W. Junk), p. 67-184.

Seibold, E. and Hinz, K., 1974. Continental slope construction and destruction, West Africa. In Burk, C. A. and Drake, C. L. (Eds.), The geology of continental margins: New York (Springer), p. 179-196.

Shepard, F. P. and Dill, R. F., 1966. Submarine canyons and other sea valleys: Chicago (Rand McNally).

Stanley, D. J. (Ed.), 1969. The new concepts of continental margin sedimentation: Washington (Am. Geol. Inst.). , 1970. Flyschoid sedimentation on the outer Atlantic margin off northeast North America. In Lajoie, J. (Ed.), Flysch sedimentology in North America: Geol. Assoc. Canada, Spec. Paper 7, p. 179-210.
1974. Pebbly mud transport in the head of Wilmington Canyon, Marine Geol., v. 16, p. M1-M8. 975. Submarine canyon and slope sedimentation (Gres d'Annot) in the French Maritime Alps, Ninth Internat. Congr. Sedimentology, Nice, Guidebook.

Stanley, D. J. and Silverberg, N., 1969. Recent slumping on the continental slope off Sable Island Bank, Southeast Canada, Earth Planet. Sci. Lett., v. 6, p. 123-133.

Stanley, D. J. and Unrug, R., 1972. Submarine channel deposits, fluxoturbidites and other indicators of base-ofslope environments in modern and ancient marine basins. In Rigby, J. K. and Hamblin, W. K. (Eds.), Soc. Econ. Paleont. Mineral. Spec. Pub. 16, p. 287-340.

Stoll, R. D., 1974. Effects of gas hydrates in sediments. In Kaplan, I. R. (Ed.), Natural gases in marine sediments: New York (Plenum Press), p. 235-248.

Summerhayes, C. P., Milliman, J. D., Briggs, S. R., Bee, A. G., and Hogan, C., 1976. Northwest African shelf sediments: influence of climate and sedimentary processes, J. Geol., v. 84, . 277-300.

Tucholke, B. E. and Carpenter, G. B., in press. Sediment distribution and Cenozoic sedimentation dynamics on the Agulhas Plateau, Geol. Soc. Am. Bull.

Vail, P. R., Mitchum, R. M., Jr., and Thompson, S., 1977. Seismic stratigraphy and global changes of sea-level, Part 3: Relative changes of sea-level from coastal onlap, $\mathrm{Am}$. Assoc. Petrol. Geol. Mem. 26, p. 63-98.

von Rad, U., 1968. Comparison of sedimentation in the Bavarian Flysch (Cretaceous) and recent San Diego Trough (California), J. Sediment. Petrol., v. 38, p. 1120-1154.

von Rad, U., Čepek, P., von Stackelberg, U., Wissmann, G., and Zobel, B., 1978. Cretaceous and Tertiary sediments from the northwest African slope (dredges and cores supplementing DSDP results), Marine Geol., v. 28.

Walker, R. G. and Mutti, E., 1973. Turbidite facies and facies associations. In Turbidites and deep-water sedimentation-lecture notes, Soc. Econ. Paleont. Mineral., Pacific Section, p. 119-158 



\section{PLATE 1}

Lithofacies of type section in Sections 397-87-1 and 2 . Lithofacies types as defined in text: F-1: foraminiferal quartz sandstone, calcite cemented; F-2: lighter colored mud turbidite; F-3; dark colored, organic carbon-rich mud turbidite; F- $4 \mathrm{~A}_{1}$ : dark colored, disorganized, poorly-sorted pebbly mudstone; F-5: burrowed, light colored nannofossil marl (autochthonous). b: burrowed, g: graded, m: massive, homogeneous, l: laminated.

Note sparse burrows, mostly near top, distinct parting, and sharp basal contacts on F-2 and F-3. These two facies are typically mudstones or silty mudstones. They may grade upward from a basal laminated foraminiferal quartz sand or silt as at Sample $397-87-1,116 \mathrm{~cm}$. Facies F-2, F-3, and F-4 often gradually pass upward into intensely burrowed, more calcareous F-5. In this core $\mathrm{F}-4 \mathrm{~A}_{1}$ is characterized by rounded, dark colored mudstone pebbles and rare fragments of shallow-water calcareous organisms. 
PLATE 1
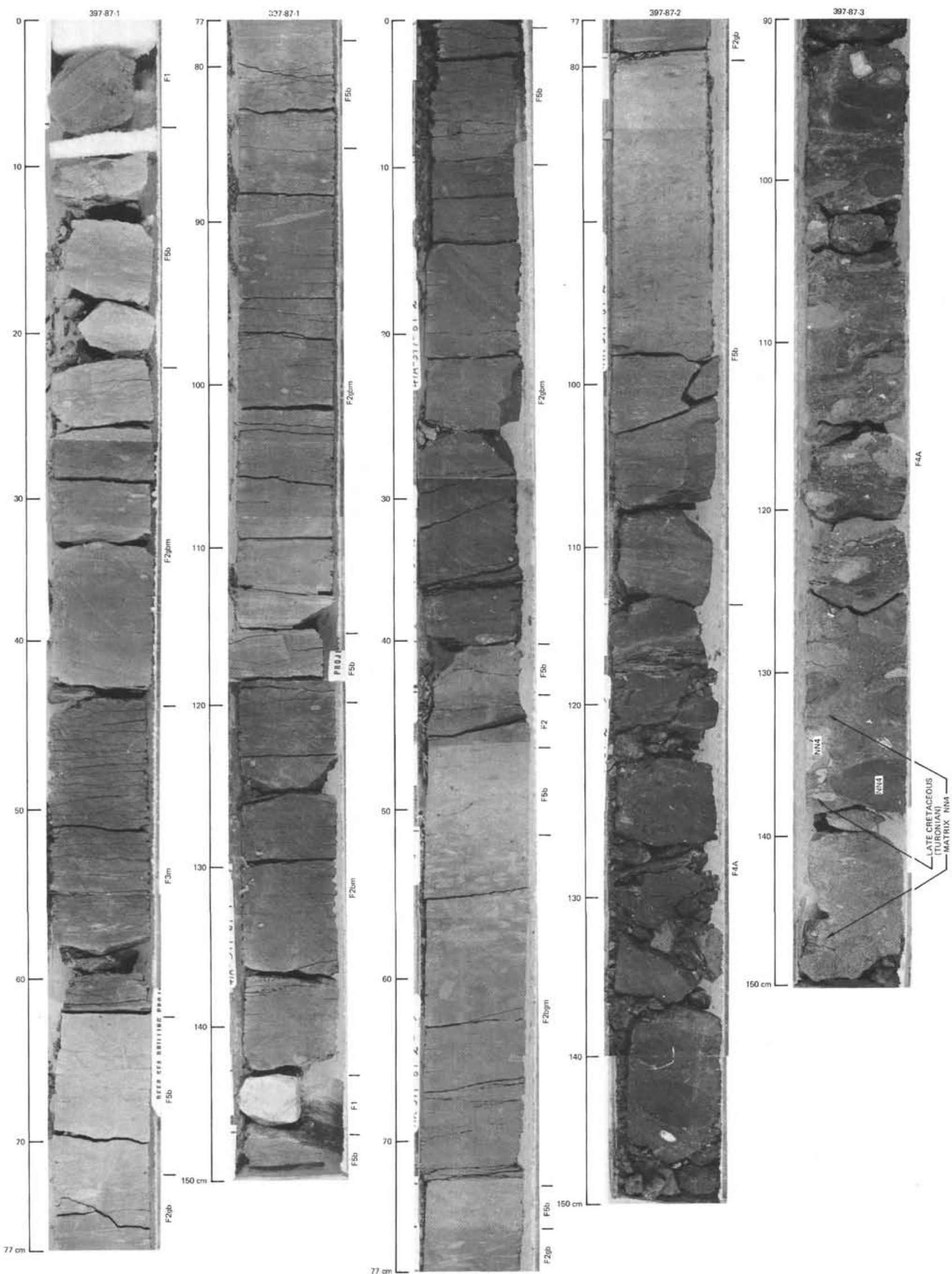
PLATE 2

Bedding and Bioturbation Phenomena in the Autochthonous Neogene of Site 397 (Facies F-5, middle to late Miocene examples)

Figure 1 Sample 397-66-1, 91-124 cm; lamination, streaky lamination (elongated small burrows) and bioturbation in $(5 \mathrm{G} 6 / 1)$ greenish gray marly nannofossil chalk. Most of core is highly bioturbated, lamination is somewhat unusual. Streaks and lamination in this sample could be due to shear induced by about 20-cm-thick slump unit just above.

Figure 2 Sample 397-73-3, 115-146 cm; fine (streaky) lamination, mottling, "halo" burrows in nannofossil chalk. Numerous specks and burrow fillings of pyrite. Much of lamination in this case might be diagenetic in origin similar to burrow halos which appear to be dark greenish blue "reduction fronts" - presumably a liesegang-type phenomenon. In other examples horizontal laminae pass directly through burrows.

Figure 3 Sample 397-60-2, 115-147 cm; bioturbation and indistinct mottling in olive-gray nannofossil chalk (5Y $5 / 2$ ); burrows typically composite with thin organic linings. This is the typical expression of Facies F-5.

Figure 4 Sample 397-60-5, 120-150 cm; $30 \mathrm{~cm}$ long vertical burrow (probably Teichichnus) about $0.5-1.5 \mathrm{~cm}$ wide in light olive-gray (5GY 6/1) nannofossil chalk. Other recognizable trace fossils in F-5 include Chondrites and Zoophycos. 
PLATE 2
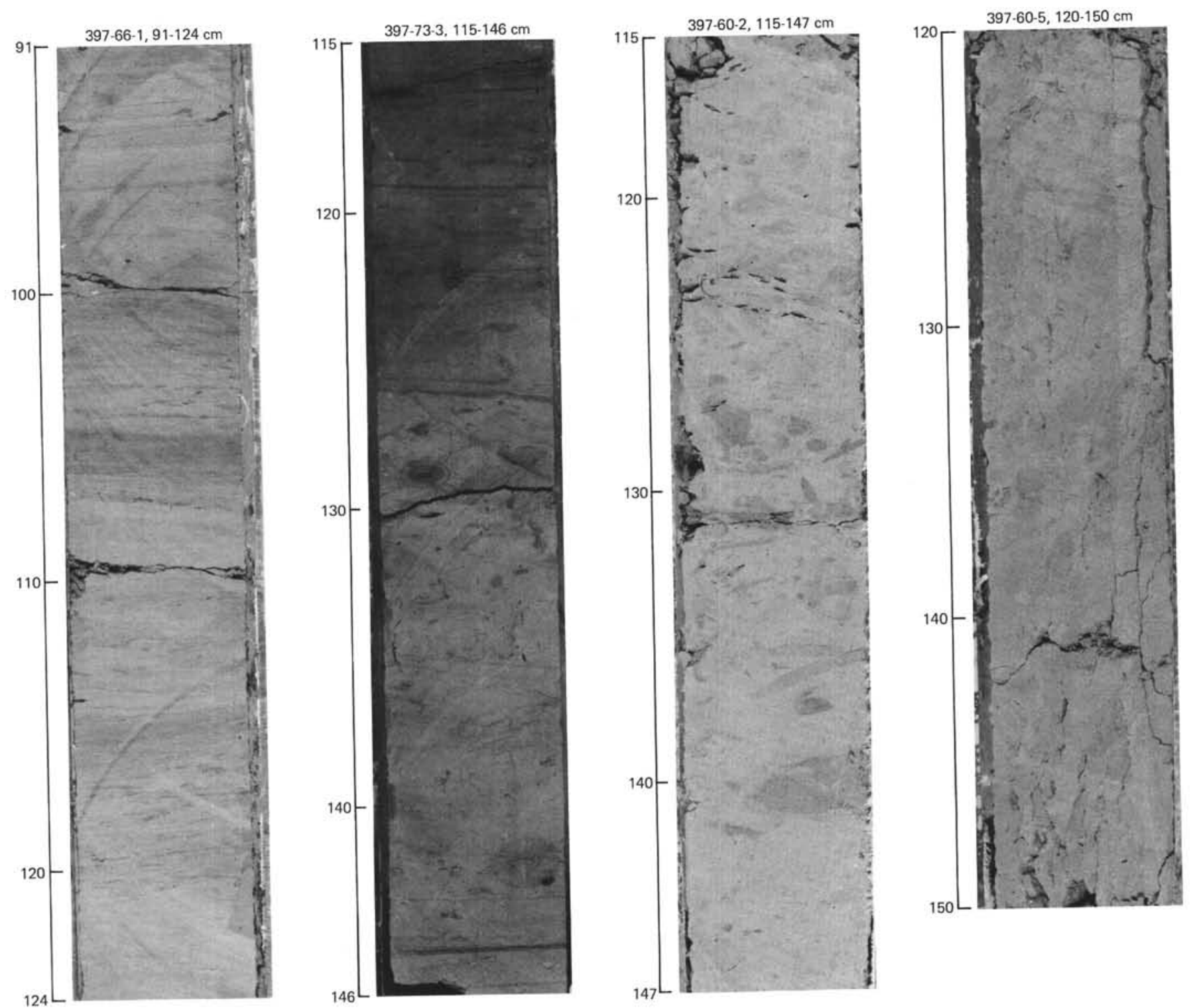


\section{PLATE 3}

Thin-section Photomicrographs of Autochthonous

Neogene Sediment (F-5)

Figure 1 Photo of entire thin section 397-78, CC, $5-8 \mathrm{~cm}$. Foraminiferal marlstone with about 20 per cent planktonic foraminifers and traces of silt-sized quartz in a micritic marly matrix; some indistinct lamination and concentrations of silt-sized detritus as in burrow mottles. Tests of foraminifers are calcite filled.

Figure 2 Photo of entire thin section 397A-28, CC. Silicified dark claystone of early Miocene age. Abundant elongate lenses and layers of lighter colored silty claystone containing 20 per cent siltsized quartz and authigenic silica (opal-CT) with clay minerals. The lenses appear to be compacted and/or slightly sheared burrows which concentrated coarser material; however, they may also be flattened small clasts of silty mudstone. In this case it is difficult to distinguish F-5 from the upper portion of an F-2 layer. 
PLATE 3
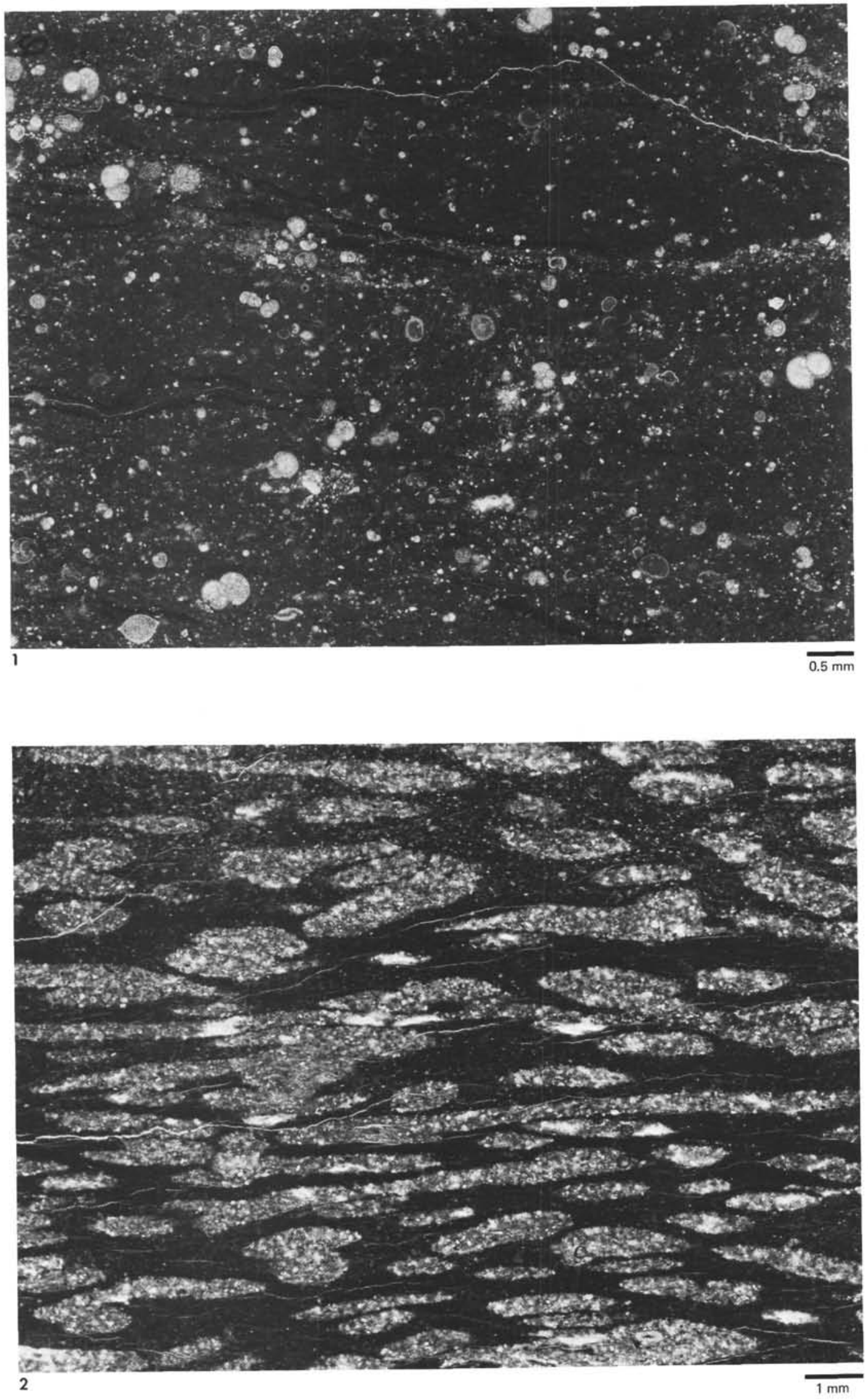
Examples of Slump Structures

Figure 1 Sample 397A-16-3, 4-49 cm. A 44-cm portion of a semiconsolidated slump unit at least 8 meters thick, part of which is shown in sketch to right of photo. Tight to gentle folding, disruption of layers and floating clasts are typical of this and similar units; individual dark and light mudstone layers are stretched and pulled apart. This unit represents a mixture of F-5 (light colored burrowed) and F-3 facies (dark colored layers). The appearance of this slump unit is similar to or transitional to some $\mathrm{F}-4 \mathrm{~A}_{2}$ facies units which are more disorganized and disrupted during flowage and liquification.

Figure 2 Sample 397-68-1, 2-28 cm. Series of tight, overturned folds in slump zone XVI (see Site Report Barrel Sheet) of lithostratigraphic Unit 3 of mostly greenish gray (5G 6/1) marly nannofossil chalk. Age of sediment in slump is coeval with that of undisturbed section above and below. Lamination appears to result from alongation of burrowed horizons by ductile stretching during downslope movement and flowage. Sediment was probably derived from just upslope of the site and deformed by slow flowage.

Figure 3 Sample 397-61-5, 26-52 cm. Another example of structure formed in slumped units of mainly autochthonous sequence in lithostratigraphic Unit 3 (slump zone XXII, see Barrel Sheets); note discordant laminations, swirled wisps and pseudoflame structure. Truncated dipping sets of laminae may be due to movement along subhorizontal fault planes during flowage (not core disturbance). 
PLATE 4
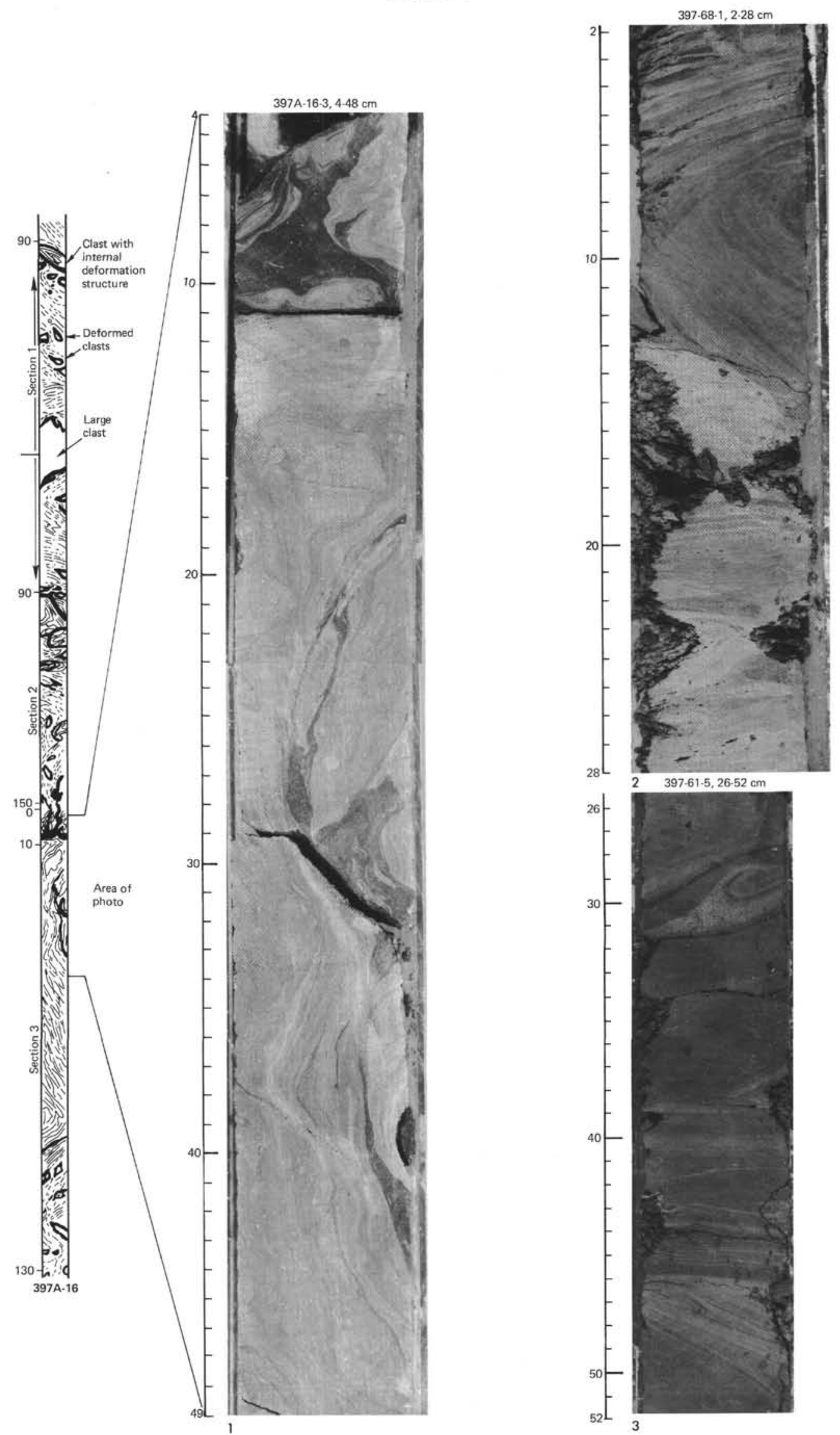


\section{PLATE 5}

Core Photos of Laminated, Graded, and Massive Sand Layers (turbidites and contourites [?], Lithofacies (FIA)

Figure 1 Sample $397-71-1,117 \mathrm{~cm}$ to $71-2,27 \mathrm{~cm}$. Thick massize graded sand layer (proximal turbidite[?]); Facies F-1A about $60 \mathrm{~cm}$ thick is the thickest such layer recovered at Site 397. Sharp basal contact but lowermost $23 \mathrm{~cm}$ somewhat disturbed by drilling. Color grades from dark gray (5Y 4/1) at base to gray $(5 \mathrm{Y} 7 / 1)$ at top. Lower portion contains coarse-grained sand including rounded claystone and limestone granules and calcareous shell fragments, uncemented. Upper portion shows better sorting and consists primarily of small mudstone clasts, quartz, foraminifers, and glauconite. This thick sand layer occurs above a major hiatus in Core 72.

Figure 2 Sample 397-76-3, 50-76 cm. Two $1-2 \mathrm{~cm}$ thick graded sand layers (F-1A) with sharp lower contacts. Upper parts burrowed and overlain by bioturbated autochthonous Lithofacies F-5. Base of sand layers faintly laminated ( $\mathrm{Tb}$ of Bouma). These types of sand layers are especially common in the interval $397-78$ to $397-72$. Upper layer is olive-green (foram, quartz, glauconite) and lower one is dark brownish black (foram, quartz, volcanic glass, heavy minerals).

Figure 3 Sample 397A-2-2, 1-31 cm). Upper part (1-18 cm) several parallel laminated moderately sorted silty sandstones and sandy siltstones with sharp basal contacts. Colors from light gray (N6) to black (N1); light gray interval (e.g., at $13 \mathrm{~cm}$ ) are calcareous with clay chips, foraminifers, and unspecified carbonate grains as dominant constituents while black interval (e.g., at $5 \mathrm{~cm}$ ) consists primarily of volcanic glass and heavy minerals ( $15 \%$ opaques). Lower part of interval $(23-30 \mathrm{~cm})$ is cross-laminated, well-sorted coarse silt and fine sand with climbing ripple structure; light and dark alternations are foraminifer quartz-rich and volcanic detritus-rich, respectively. Sediment of this interval may have a contourite origin (see Plate 6, Figure 2). 


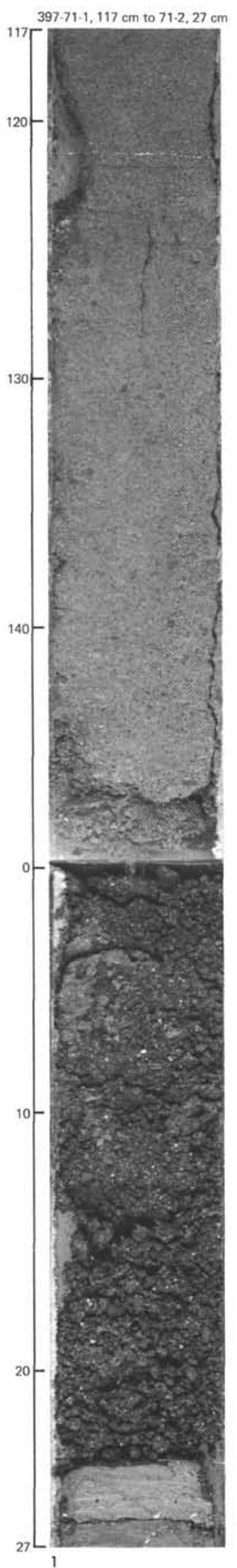

PLATE 5
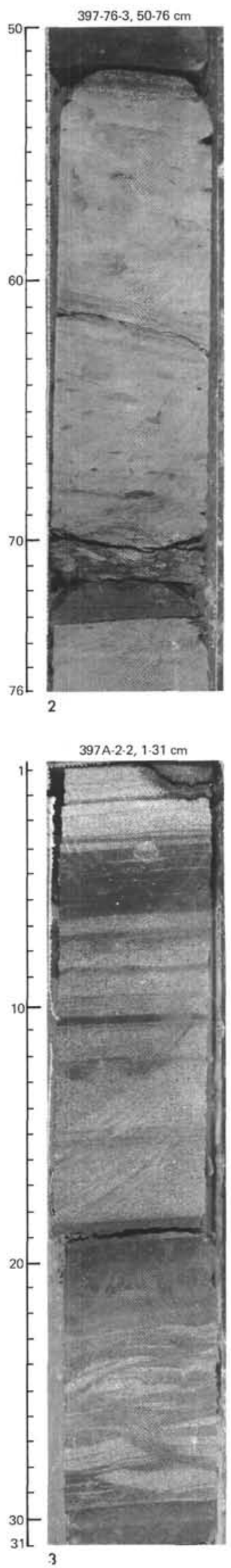
PLATE 6

Thin-section Photomicrographs of Turbidites and Contourites(?) (F-1A)

Figure 1 Sample 397-A-2-2, 24-29 cm, crossed nicols. Upper-right corner, moderately sorted quartz siltstone to very fine grained sandstone (as in Figure 1). Major part of thin section is a laminated sand-sized foraminiferal packstone, with 55 per cent planktonic foraminifer tests partially or entirely filled with micritic calcite, 20 per cent angular quartz, 15 per cent altered volcanic rock fragments, 3 per cent glauconite, and traces of volcanogenic material in sparse clay matrix. Lithofacies F-1A (contourite or contour-current reworked turbidite[?]).

Figure 2 Sample 397A-3-1, 8-10 cm, plane light. Wellsorted calcite-cemented very fine grained quartz sandstone with 50 per cent angular quartz (60-150 $\mu \mathrm{m})$, traces of feldspar, 5 per cent foraminifers; probably a distal turbidite (F-1A, occurs at top of F-4A unit).

Figure 3 Sample 397-78-3, 63-65 cm, plane light. From a 4 $\mathrm{cm}$ dark gray sandy siltstone layer with sharp basal contact and prominent horizontal parting. Angular coarse silt to fine-grained sand, moderate sorting with benthic and planktonic foraminifers, quartz, mudclasts, and heavy minerals. 
PLATE 6
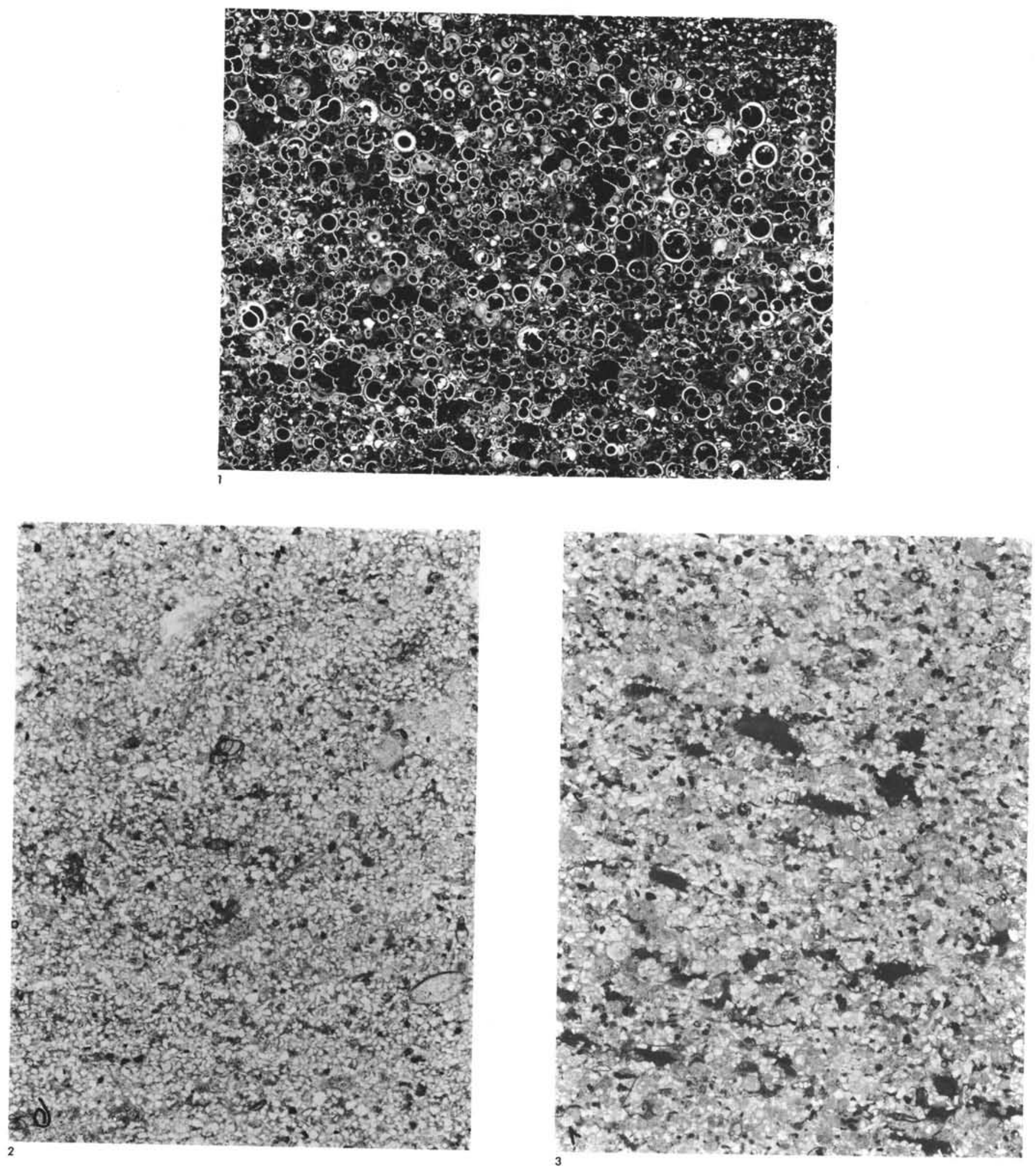
PLATE 7

Core and Thin-section Photos of Turbiditic Mudstones (Lithofacies F-3; early Miocene to middle Miocene)

Figure 1 Sample 397-76-3, 25-35 cm. Thin dark olive-gray mud turbidite $(\mathrm{F}-3,30-34 \mathrm{~cm})$ with sharp basal contact and burrowed upper portion in contact with burrowed F-5 above (see Plate 1 for other thicker examples of F-3).

Figure 2 Sample 397A-16-6, CC; plane light, entire thin section. Laminated quartzose silty claystone $(=$ siderite micrite) with phosphatized layers $(70 \%$ siderite, $10 \%$ collophane, $15 \%$ clay minerals, $5 \%$ silt-sized quartz). Apparently a laminated mud turbidite $(\mathrm{F}-3 l)$ but may be large clast in debris flow derived from upper slope. Sample comes from plastically deformed and folded slump unit or debris flow (?) (F-4A).

Figure 3 Sample 397A-11-7, CC, plane light. Laminated, silty quartzose mudstone with layers rich in quartz silt and benthic foraminifers, phosphate, and glauconite (F-3l and matrix of F-4A). Occurs interbedded in sequence of debris flow units $(\mathrm{F}-4 \mathrm{~A})$.

Figure 4 Sample 397A-11-2, 92-95 cm, plane light. Foraminiferal, quartzose clayey sandstone with 60 per cent benthic foraminifers (mainly Buliminacea derived from upper slope), 10 per cent terrigenous quartz $(30-100 \mu \mathrm{m})$ and 30 per cent carbonate-free clay matrix. This is an example of Lithofacies F-3l interbedded with debris flow units (F-4A); the layer is $12 \mathrm{~cm}$ thick, dark olive-green (5Y 3/2) and exhibits wavy lamination.

Figure 5 Sample 397A-24-2, 63-65 cm, plane light. Coarsegrained basal part of more than 2 meters thick mud turbidite (F-3) interbedded in sequence of debris flow units. Poorly sorted fine-grained siltstone (basal part) rich in benthic foraminifers $(20 \%)$, mud-clasts or chips $(20 \%)$, angular quartz $(15 \%)$, glauconite $(5 \%)$, echinoid debris, phosphates, and fish debris (Lithofacies F-3g-l). Most material probably derived from upper-slope or outer shelf. 
PLATE 7
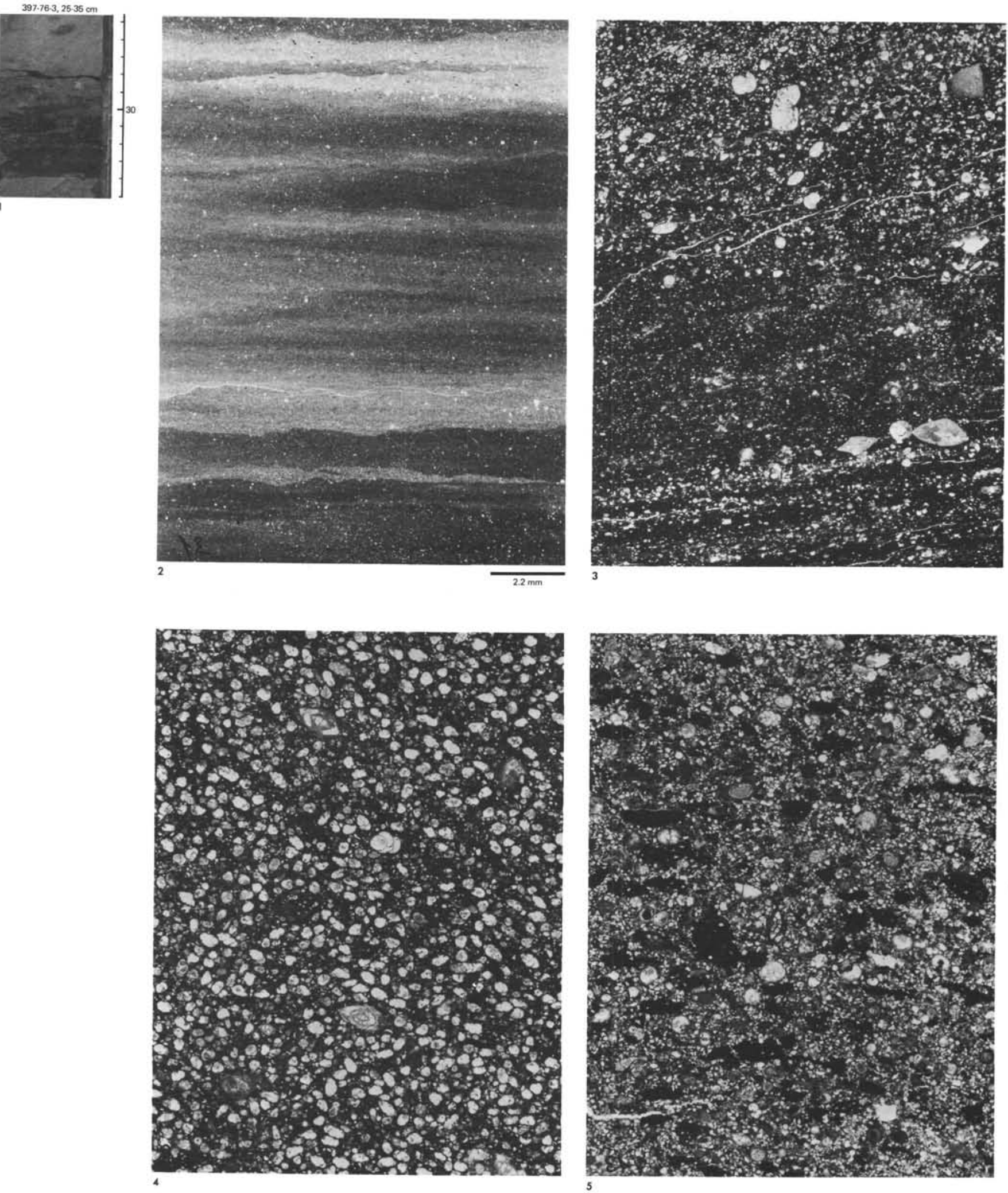


\section{PLATE 8 \\ Core Photos Showing Sedimentary Fabric of Pebbly Mudstones (F-4)}

Figure 1 Sample 397-80-3, 26-45 cm. Medium blue grain (5B 5/1) muddy, granular sand, $15 \mathrm{~cm}$ thick, partly graded, and laminated. Contains predominantly planktonic and benthic foraminifers, quartz, and angular mudstone chips and granules (dark brown to dark gray); mud clast-rich layers alternate with quartz-rich layers of medium to coarsegrained sandstones. Rather atypical sandstone unit in upper part of displaced sediment sequence of middle Miocene age (Transitional F-4A to F-1).

Figure 2 Sample 397A-13-1, 14-29 cm. Stretched, necked, and pulled apart, plastically-deformed mudstone and marly nanno ooze (now lithified), pebbles floating in somewhat laminated matrix of dark olive-gray (5Y 3/2) nannofossil marlstone of early Miocene age $\left(\mathrm{F}-4 \mathrm{~A}_{2}\right)$. Stretched lamination dipping at $30^{\circ}-40^{\circ}$, possibly a detached chaotic slump unit; interbedded with more easily recognizable slump units.

Figure 3 Sample 397A-14-4, 3-23 cm. Another example of debris flow deposit $\left(\mathrm{F}-4 \mathrm{~A}_{2}\right)$ with chaotic assortment of contorted and plastically deformed (flowage) mudstone and marly nannofossil ooze pebbles (light colored).

Figure 4 (Sample 397A-16-2, 84-110 cm). Contorted and squeezed pebbles or sedimentary layers in pebbly mudstone $\left(\mathrm{F}-4 \mathrm{~A}_{2}\right)$. Indurated light colored portions are marly nannofossil chalks of Oligocene (NP 24) age set in probably early Miocene matrix of dark, organic-carbon-rich mud. Note slip folding and overturned folds. This interval is transitional between a slump unit and debris flow. 


\section{PLATE 8}
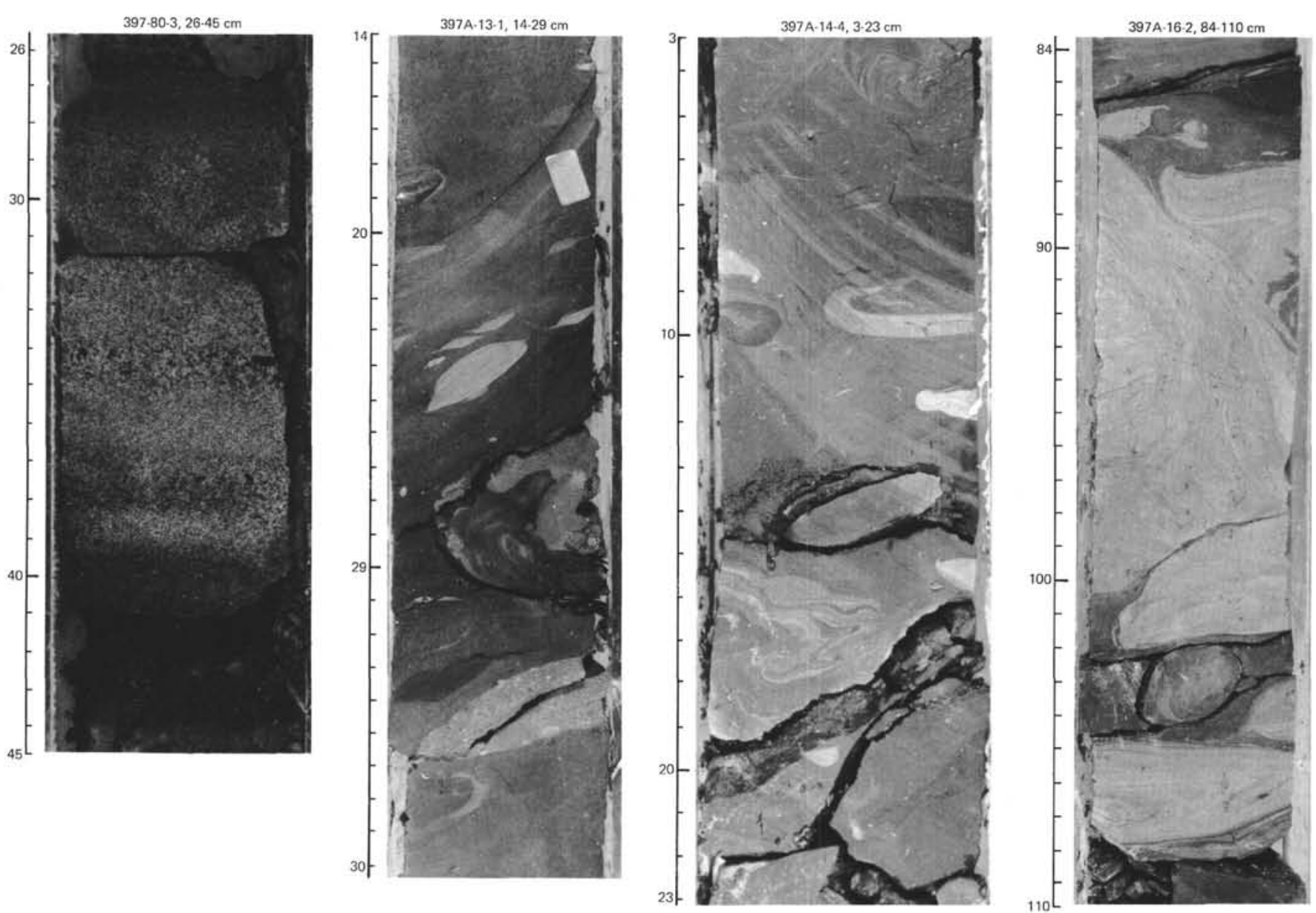


\section{PLATE 9}

Thin-section Photomicrographs of Matrix of Pebbly Mudstones (F-4A, B, C)

Figure 1 Photo of entire thin section in plane light, Sample $397-78-4,39-43 \mathrm{~cm}$. Poorly sorted pebbly sandy marlstone (carbonate-clay matrix) (Lithofacies F-4A/B). Large pebble at center right is quartzite (recrystallized chert from Mesozoic sequence exposed on Fuerteventura(?); just below pebble is a $\mathrm{K}$-feldspar granule; round fragment (to left of feldspar) is oncoid overgrown by bryozoan (shallow-water source; see also Schmincke and von Rad, this volume); another oncoid at lower left. Several volcanic rock fragments (e.g., center left) suggest derivation from Canary Islands (Fuerteventura[?]).

Figure 2 Sample 397-102-1, CC; entire section in plane light. Very poorly sorted quartzose sandy pebbly mudstone (quartz modes: $60-200 \mu \mathrm{m} ; 200-500 \mu \mathrm{m}$; 2-4 mm). Dark fragments are phosphatic oolite and fish detritus (Lithofacies F-4C). 
PLATE 9
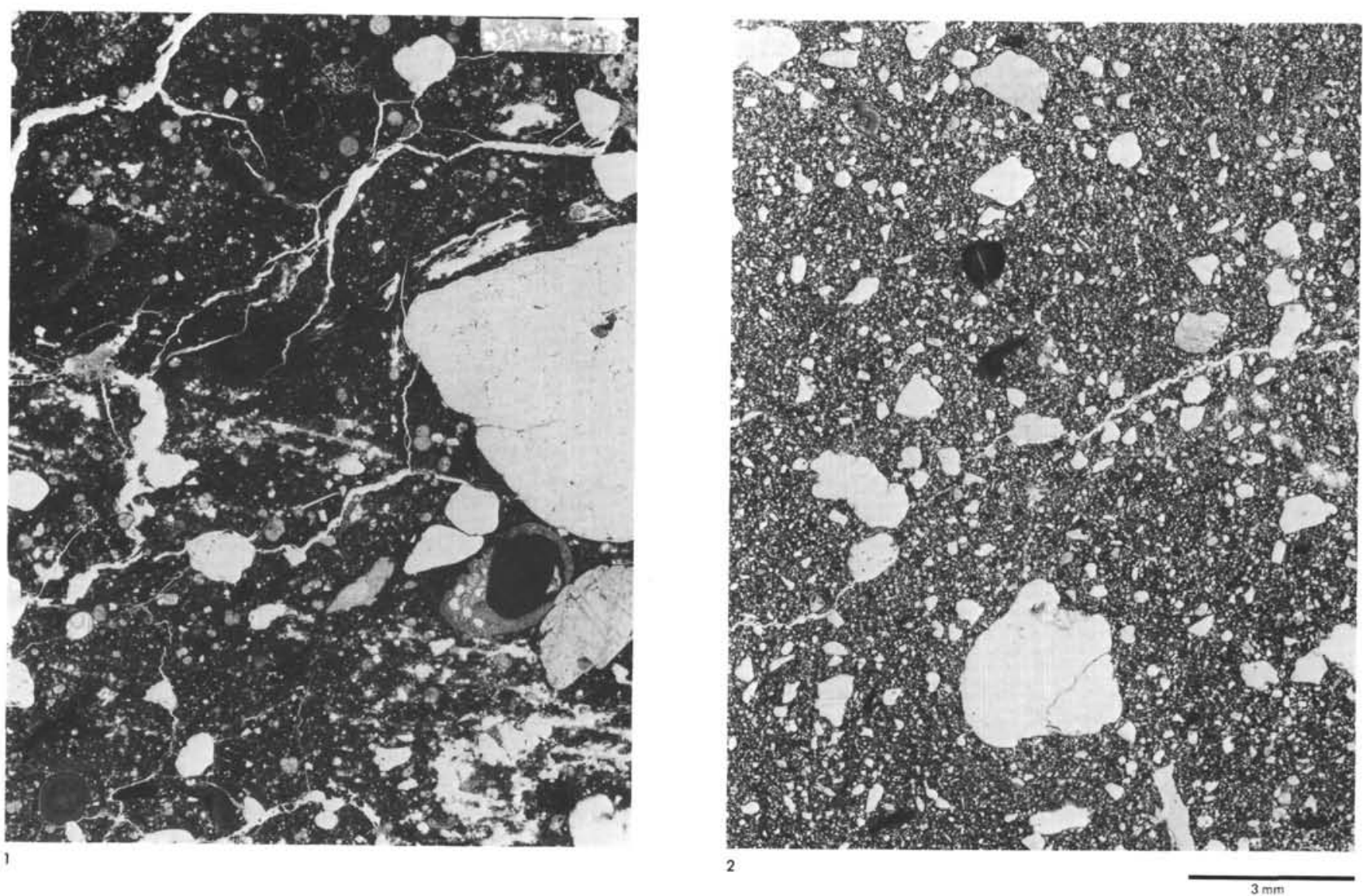
PLATE 10

Thin-section Photomicrographs of Pebbly Mudstone

Matrix (F-4A)

Figure 1 Sample 397A-2, CC, plane light. Poorly sorted pebbly sandstone with well-sorted matrix of calcite cemented quartz sandstone $(50-100 \mu \mathrm{m})$ and a few shelf-derived large calcareous bioclasts (echinoids, lower right; mollusks; benthic foraminifers) and fish fragments (Lithofacies F4B).

Figure 2 Sample 397A-3, CC, plane light. Poorly sorted clayey quartz sandstone overlying silty mudstone with clayey silt-layers showing small scale slump fold $\left(\mathrm{F}-4 \mathrm{~A}_{1}\right)$. 
PLATE 10
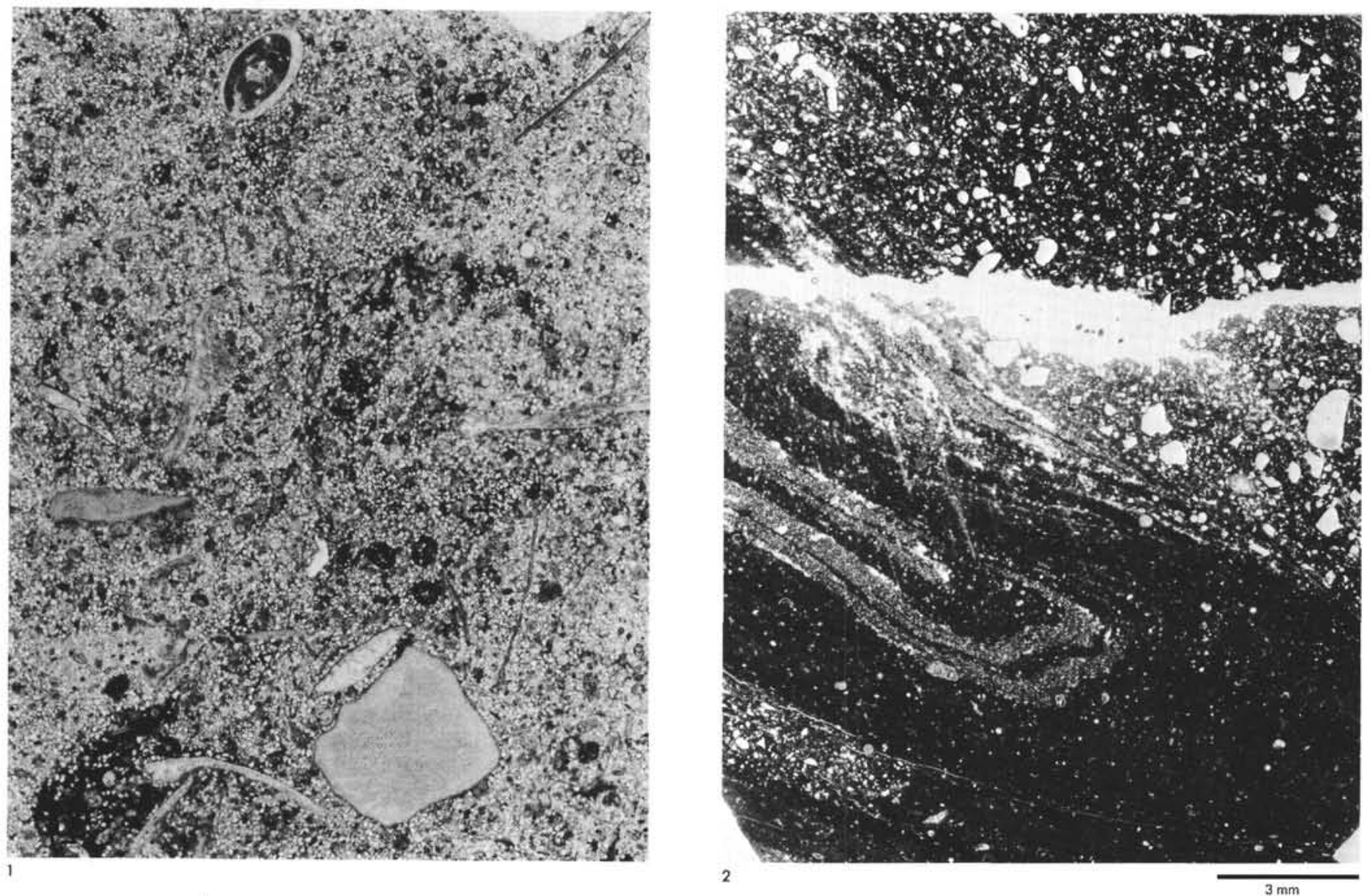